

\section{DISCLAIMER}

This report was prepared as an account of work sponsored by an agency of the United States Government. Neither the United States Government nor any agency Thereof, nor any of their employees, makes any warranty, express or implied, or assumes any legal liability or responsibility for the accuracy, completeness, or usefulness of any information, apparatus, product, or process disclosed, or represents that its use would not infringe privately owned rights. Reference herein to any specific commercial product, process, or service by trade name, trademark, manufacturer, or otherwise does not necessarily constitute or imply its endorsement, recommendation, or favoring by the United States Government or any agency thereof. The views and opinions of authors expressed herein do not necessarily state or reflect those of the United States Government or any agency thereof. 


\section{DISCLAIMER}

Portions of this document may be illegible in electronic image products. Images are produced from the best available original document. 


\section{Printed in the United States of America. Available from National Tcchnical Information Service \\ U.S. Department of Commerce \\ 5285 Port Royal Road, Springfield, Virginia 22161 \\ NTIS price codes-Printed Copy: A05 Microfiche A01}

This report was prepared as an account of work sponsored by an agency of the United States Government. Neither the United States Government nor any agency thereof, nor any of their employees, makes any warranty, express or implied, or assumes any legal liability or responsibility for the accuracy, completeness, or usefulness of any information, apparatus, product, or process disclosed, or represents that its use would not infringe privately owned rights. Reference herein to any specific commercial product, process, or service by trade name, trademark, manufacturer, or otherwise, does not necessarily constitute or imply its endorsement, recommendation, or favoring by the United States Government or any agency thereof. The views and opinions of authors expressed herein do not necessarily state or reflect those of the United States Government or any agency thereof. 
This book was prepared as an account of work sponsored by an agency of tha United States Government. Wather the United Siates Government nor any ageney thereot, nor any of their employees. makes any

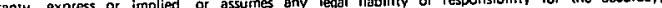
complereness, of useftutness of any information, apparatus. product. or process olsclosed, or

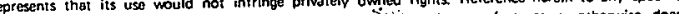

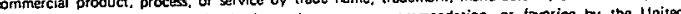

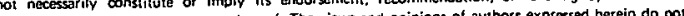

States Government or any agency thereot. The views and opinions of achors exprased harin do not

ORNL/TM-7396

Dist. Category UC-97e

Contract No. W-7405-eng-26

ANALYSIS OF ENVIRONMENTAL ISSUES RELATED TO SMALL SCALE HYDROELECTRIC DEVELOPMENT

II: Design Considerations for Passing Fish Upstream Around Dams ${ }^{1}$

Edited by:

S. G. Hildebrand

Contributors:
M. C. Bel1 $1^{2}$
E. P. Richey ${ }^{2}$
J. J. Anderson ${ }^{2}$
Z. E. Parkhurst ${ }^{3}$

ENVIRONMENTAL SCIENCES DIVISION Publication No. 1567

\footnotetext{
1 Prepared for U.S. Department of Energy, Assistant Secretary for Resource Applications, Small Scale Hydropower Development Program.

${ }^{2}$ The University of Washington College of Fisheries, Seattle, Washington 98195 under ORNL Subcontract No. 7678.

${ }^{3}$ Retired from the U.S. Fish and Wildlife Service, Portland, Oregon.
}

NOTICE This document contains information of a preliminary nature. It is subject to revision or correction and therefore does not represent a final report.

Date Published: August 1980

OAK RIDGE NATIONAL LABORATORY

Oak Ridge, Tennessee 37830

Operated by

UNION CARBIDE CORPORATION

for the

DEPARTMENT OF ENERGY 


\section{THIS PAGE}

\section{WAS INTENTIONALLY \\ LEFT BLANK}




\section{ACKNOWLEDGMENTS}

Appreciation is extended to the following individuals, whose suggestions and comments were most useful in preparing this report: Ben Rizzo, U.S. Fish and Wildlife Service; and Larry Barnthouse, Glenn Cada, and Webster Van Winkle, Oak Ridge National Laboratory. This study was funded by the U.S. Department of Energy, Assistant Secretary for Resource Applications, Small Scale Hydropower Development Program. 


\title{
THIS PAGE
}

\section{WAS INTENTIONALLY}

\author{
LEFT BLANK
}

IV 
FOREWORD

This document is based on a subcontract report submitted to Oak Ridge National Laboratory by Milo C. Be 11, Professor Emeritus, The University of Washington College of Fisheries, Seattle, Washington. The study was funded by the U.S. Department of Energy, Assistant Secretary for Resource Applications, Small Scale Hydroelectric Development Program. The purpose of the document is to provide general information for use by potential developers of small scale hydroelectric projects that will include facilities to pass migrating fish upstream around dams.

The document is not intended to be a textbook on design of fish passage facilities, but rather to be a general guide to some factors that are important when designing such facilities.

Section 2 of this report (General Life History and Distribution of Fish Species That May Require Fish Passage), prepared by Zell Parkhurst, acquaints the lay reader with biological information on select fish species that may require passage. Section 3 (Some Biological Factors Related to Upstream Fish Passage Around Dams), by James Anderson, reviews and synthesizes pertinent literature on which many of the design criteria that follow are based.

The senior contributor to this document, Milo C. Bell, has spent over 40 years of his professional life as a researcher, teacher, and consultant in this field. Section 4 (General Types of Upstream Passage Facilities) and Section 5 (General Design Considerations) describe some of the more important design considerations resulting from his collective experience. Selected references at the end of Section 5 provide an entry into relevant 1 iterature.

Section 6 (Comparative Cost Estimates for Basic Upstream Passage Facilities), by Milo Bell and Eugene Richey, provides general information on cost for use during preliminary feasibility studies in 
determining the potential for a given small hydroelectric site. The major conclusions resulting from the overall study are briefly summarized in Section 7.

Historically, design specifications for fish passage systems have been reported in "English" units of measure. In this report information is reported in metric (SI) units, but English units are given in parentheses. Many comments received on early drafts of this report indicated that this system would be more useful for readers than using metric units only. All metric values were rounded to one decimal place.

This document is the secund in a series of reports addressing environimental issues and smali scale hydroelectric technolngy that, are being prepared by Uak Kidge National Laboratory for the Department of Energy. The first report in this series (Analysis of Environmental Issues Related to Small Scale Hydroelectric Development. I: Dredging by J. M. Loar, L. L. Dye, R. R. Turner, and S. G. Hildebrand, ORNL/TM-7228) is available from the National Technical Information Service, U.S. Department of Commerce, 5285 Port Royal Road, Springfield, Virginia 22161.

St.ephen G. Hildobrand Environment.al Sriences Division Oak Ridge National Laboratory Oak Ridge, Tennessee 37830 


\section{ABSTRACT}

HILDEBRAND, S. G. (Editor). 1980. Analys is of environmental issues related to small scale hydroelectric development. II. Design considerations for passing fish upstream around dams. ORNL/TM7396. Oak Ridge National Laboratory, Oak Ridge, Tennessee. $84 \mathrm{pp}$.

The possible requirement of facilities to move migrating fish upstream around dams may be a factor in determining the feasibility of retrofitting small dams for hydroelectric generation. This report addresses basic design considerations that should be evaluated on a sitespecific basis if upstream fish passage facilities are being considered for a small scale hydroelectric project (defined as an existing dam that can be retrofitted to generate $25 \mathrm{MW}$ or less). Information on general life history and geographic distribution of fish species that may require passage is presented.

Biological factors important in the design of upstream passage facilities are discussed: gas bubble disease, fish swimming speed, oxygen consumption by fish, and diel and photo behavior.

Three general types of facilities (fishways, fish locks, and fish lifts) appropriate for upstream fish passage at small scale hydroelectric projects are described, and size dimensions are presented. General design criteria for these facilities (including fish swimming ability and behavior) and general location of facilities at a site are discussed. Basic cost considerations for each type of passage facility, including unit cost, operation and maintenance costs, and costs for supplying attraction water, are indicated. 
This report is intended only to provide background information useful for initial stages of analysis of fish passage requirements at a given site. Final design of fish passage facilities should be accomplished with the assistance of recognized expertise available from state and Federal agencies, universities, and private firms. 
ACKNOWLEDGMENTS ................................ $\frac{\text { Page }}{i i i}$

FOREWORD . . . . . . . . . . . . . . . v

ABSTRACT . . . . . . . . . . . . . . . . . vi

LIST OF TABLES . . . . . . . . . . . . . . . . . . . . $\quad x i$

LIST OF FIGURES . . . . . . . . . . . . . . . . . . . xi

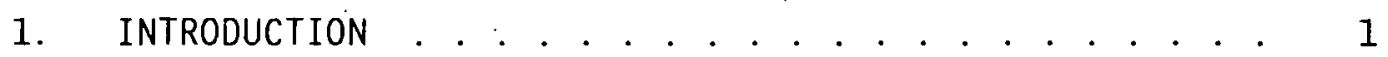

2. GENERAL LIFE HISTORY AND DISTRIBUTION OF

3. SOME BIOLOGICAL FACTORS RELATED TO UPSTREAM FISH PASSAGE AROUND DAMS . . . . . . . . . 25

3.1 Gas Bubble Disease . . . . . . . . . . . . 25

3.2 Fish Swimming Speed . . . . . . . . . . 27

3.3 0xygen Consumption .......... . . . 32

3.4 Schooling Behavior............ . . 34

3.5 Diel and Photo Behavior ......... 35

REFERENCES . . . . . . . . . . . . . . 36

4. GENERAL TYPES OF UPSTREAM FISH PASSAGE
FACILITIES . . . . . . . . . . . . . . 39

4.1 Pool and Weir Fishway. . . . . . . . . . 39

4.2 Vertical Slot Fishway . . . . . . . . . . . . . 41

4.3 Denil Fishway . . . . . . . . . . . . . . . . . . 41

4.4 Fish Lock System . . . . . . . . . . . . . . . . 41

4.5 Fish Lift System . . . . . . . . . . . . . . 45

5. GENERAL DESIGN CONSIDERATIONS FOR UPSTREAM

FISH PASSAGE FACILITIES . . . . . . . . . . . . 47

5.1 Swimming Performance and Behavior . . . . . . 48

5.2 Attraction Flows, Entrance Exit Conditions, and Typical Location of Passage Systems . . . . . 52

5.3 Check List of Pertinent Design Data . . . . . . 56

REFERENCES ................ . . 60 
TABLE OF CONTENTS (Continued)

$\underline{\text { Page }}$

6. GENERAL COST ANALYSIS ............... 63

6.1 Unit Costs for Upstream Passage Facilities. . . . 63

6.2 Cost of Supplying Attraction Water....... 64

6.3 Operating and Maintenance Costs . . . . . . . . 65

7. SUMMARY . . . . . . . . . . . . . . 67 


\section{LIST OF TABLES}

$\underline{\text { Tab le }}$

$\underline{\text { Page }}$

1 Results of telephone contacts with state agencies regarding fish passage. . . . . . . . . . . . . 5

2 Comparative sensitivity of juvenile and adult salmonids and bass to air-supersaturated water . . . . 26

3 Effect of toxic substances on swimming performance ................... . . 31

4 Check list of pertinent design data for upstream passage facilities... . . . . . . . . . 57 


\section{LIST OF FIGURES}

Figure

Page

1 Schematic representation of a pool and weir fishway. . . . . . . . . . . . . . . . 40

2 Schematic representation of a vertical slot fishway. . . . . . . . . . . . . . . . 42

3 Schematic representation of a denil fishway . . . . . : . 42

4 Schematic representation of a fish lock. . . . . . . . . 42

5 Schematic representation of a fish lift . : . . . . . . . 46

6 Schematic representation of possible location of fish passage structures... . . . . . . . . . 55 


\section{INTRODUCTION}

Development of small scale hydroelectric projects received increased emphasis during the late 1970s, partly because of efforts by the U.S. Department of Energy to stimulate such development. Small scale hydroelectric projects are defined (for this report) as existing dam systems that can be retrofitted to produce hydroelectricity with a capacity of $25 \mathrm{MW}$ or less. Environmental considerations are an integral part of technology development, and early awareness of potential environmental constraints is important for ultimate environmental acceptability:

A frequently raised environmental issue, which may affect the development of small hydroelectric technology, is the possible requirement of fish passage facilities at existing dams. State and Federal agencies may require such facilities at existing dams to enhance fish restoration programs or to correct previous passage problems through licensing of the hydroelectric project. The need for facilities to pass migrating fish species around dams may be a significant factor in determining the economic feasibility of development efforts.

Blocking upstream movement by a dam can significantly impact those fish species with a life history that includes spawning migrations. The technology that has evolved to pass adult fish around dams as they migrate upstream is extensive. If a transfer facility is installed to minimize the delays in migration and the energy expended by fish in ncgotiating the facility, the loss in spawning potential caused by blockage by a dam can be reduced. This assumes, of course, that suitable spawning habitat is available above the dam.

If adults migrating upstream are passed around dams so that they can spawn successfully, the eggs, larvae, and juveniles of those species that eventually move downstream are faced with negotiating the same dams. This downstream migration period may be the time when a population is substantially reduced. Losses of fish that are migrating downstream in their early life history stages may result from 
predation in a reservoir or from mortality as they pass through turbines or over spillways. Also, migrants that remain in a reservoir constitute a loss to a downstream fishery. The combined loss to a fishery resource from both upstream and downstream sources of mortality may be sufficient to deplete fish stocks.

This report presents information that should assist potential developers of small scale hydroelectric projects in analyzing the upstream fish passage issue at a given site. The complex nature of such an analysis is emphasized by the scope of this report. A potential developer must be aware of the life history of fish specips at the site (Section 2), bioluyical conslderations that may affect pasaage (Section 3), the types of passage facilities available (Section 4), biological and engineering design considerations (Section 5), and cost (Section 6). No single document can do justice to all these topics, and we do not imply that we have accomplished this. Although potential concern for passing downstream migratory fish may be just as significant as concern for upstream passage, this topic is not covered in this report.

The final analysis of this issue at a given site will require the specific engineering and biological expertise and knowledge available through state agencies, the U.S. Fish and Wildlifo Service, the National Marine Fisheries Service, universities, and private consulting firms. 


\title{
2. GENERAL LIFE HISTORY AND DISTRIBUTION OF FISH SPECIES THAT MAY REQUIRE FISH PASSAGE
}

\author{
by \\ Z. E. Parkhurst
}

Whether fish passage facilities may be necessary at a given small hydroelectric site is primarily determined by the species of fish inhabiting the river system or that fish and wildife agencies plan to introduce. We briefly describe here the general life history and geographic distribution of some fish species that may require passage around dams. This information can be used as a first approximation of the potential need for passage facilities at a given site. However, this information should not be considered a substitute for site-specific investigations and consultation with local authorities, which are essential for precisely determining the need for fish passage facilities.

The presence or planned introduction of certain fish species at a given site evokes a high probability that fish passage facilities may be necessary. Such species include salmon and steelhead trout, resident trout and char, American shad, and striped bass. The probability of fish passage facilities being necessary for the remaining species discussed is site-specific, but generally low for species such as sunfish, bass, crappie, and perch.

Because the coastal states, and those states in which coastal streams originate, generally have anadromous fish runs; those areas may require fish passage facilities. Areas of the Great Lakes where Paclfic salmón and steelihead trout have been introduced should be considered as coastal states when fish passage facilities are being planned. In the coastal states, it may be assumed that the same standards for fish protection that are applied to a new project will be applied to an existing structure at which power is to be developed.

States where cold-water fish, such as trout, are resident generally have required fish passage facilities or compensatory programs, along with downstream low-flow controls, to benefit these species. 
Fish and wildlife agencies in the inland and southern states were surveyed by telephone to determine their position on fish passage (Table 1). At this time, this issue is generally of minimum concern. However, the losses to the mullet and striped bass populations that have occurred in some areas because of the presence of dams are of concern. Other species, such as paddlefish and white bass, are reported to have been affected adversely by dam structures. The various coastal states have different concerns. For example, in North Carolina and South Carolina, the potential damage to fisheries (shad and striped bass in North Carolina; herring and striped bass in South Carolina) resulting from dam construction is of concern.

The telephone conversations and correspondence and the represent.ations by hydroelectric relicensing hearings indicated that the states with migratory fish runs are concerned with (1) preventing losses to the spawning and rearing areas for such species and (2) extending their range whenever possible. State and Federal agencies are attempting to reintroduce runs of fish in numerous areas, as through programs aimed at reestablishing the Atlantic salmon and American shad runs. Passage of the warmwater species appears to be of less concern, and in some cases, additional introductions into fully populated streams may raise some objections. 
Table 1. Results of telephone contacts with state agencies regarding fish passage

\begin{tabular}{|c|c|c|c|c|c|c|c|}
\hline State & $\begin{array}{l}\text { Agencies } \\
\text { contacted }\end{array}$ & $\begin{array}{l}\text { Is fish passage } \\
\text { generally con- } \\
\text { sidered necessary? }\end{array}$ & $\begin{array}{l}\text { Do the native species } \\
\text { present problems of } \\
\text { passage at dams? }\end{array}$ & $\begin{array}{l}\text { Type of passage } \\
\text { used at dams }\end{array}$ & $\begin{array}{l}\text { Research on } \\
\text { fish passage }\end{array}$ & $\begin{array}{l}\text { General problems } \\
\text { of passage }\end{array}$ & $\begin{array}{c}\text { Comments on other } \\
\text { problems }\end{array}$ \\
\hline Alabama & $\begin{array}{l}\text { Dept. Conserv. } \\
\text { \& Nat. Res. }\end{array}$ & No & Yes & $\begin{array}{l}\text { Use navigation } \\
\text { locks }\end{array}$ & NC & & \\
\hline Arkaרsas & $\begin{array}{l}\text { Game \& Fish } \\
\text { Comm. }\end{array}$ & No & - No & . . & No & $\begin{array}{l}\text { Would like fish } \\
\text { to remain in } \\
\text { reservoirs for } \\
\text { weed control }\end{array}$ & $\begin{array}{l}\text { Low head dams are } \\
\text { topped by floods } \\
\text { (downstream) }\end{array}$ \\
\hline Georgia & $\begin{array}{l}\text { Dept. Nat. } \\
\text { Resources }\end{array}$ & NC & Yes & None specified & $\begin{array}{l}\text { Done by } \\
\text { other } \\
\text { agencies }\end{array}$ & Low streamflow & Power peaking \\
\hline Indiana & $\begin{array}{l}\text { Dept. Nat. } \\
\text { Resources }\end{array}$ & Yes & Yes & Fishways & $\begin{array}{l}\text { With } \\
\text { Michigan }\end{array}$ & $\begin{array}{l}\text { Limited to } \\
\text { migrating areas; } \\
\text { specifically with } \\
\text { introduced steel- } \\
\text { head }\end{array}$ & . \\
\hline lowa & $\begin{array}{l}\text { Conservation } \\
\text { Comm. }\end{array}$ & Yes & No & Fishways & . & & $\begin{array}{l}\text { Fish do not use } \\
\text { fishways }\end{array}$ \\
\hline Kentucky & $\begin{array}{l}\text { Dept. Fish. \& } \\
\text { Wildl. Resources }\end{array}$ & No & No & $\begin{array}{l}\text { Use navigation } \\
\text { locks }\end{array}$ & No & & $\begin{array}{l}\text { Low head dams are } \\
\text { topped by floods } \\
\text { (downstream) }\end{array}$ \\
\hline Louisiana & $\begin{array}{l}\text { Dept. Wildl. } \\
\text { \& Fish. }\end{array}$ & No & No & -- & $\begin{array}{l}\text { Development } \\
\text { of land-locked } \\
\text { populations }\end{array}$ & & \\
\hline Michigan & $\begin{array}{l}\text { Dept. Fish. } \\
\text { \& Game }\end{array}$ & Yes & Yes & Fish ladders & Yes & $\begin{array}{l}\text { Laddering of new } \\
\text { and old dams to } \\
\text { expand the range } \\
\text { of salmon and } \\
\text { steelhead }\end{array}$ & . \\
\hline Minnzsota & $\begin{array}{l}\text { Dept. Nat. } \\
\text { Resources. }\end{array}$ & Yes & Yes & NC & $\begin{array}{l}\text { Downstream } \\
\text { migrants at } \\
\text { intakes. }\end{array}$ & & $\begin{array}{l}\text { Additional dams } \\
\text { could block steel- } \\
\text { head runs in Lake } \\
\text { Superior or tribu- } \\
\text { taries }\end{array}$ \\
\hline Mississippi & $\begin{array}{l}\text { Fish \& Game } \\
\text { Comm. }\end{array}$ & No, & No & $\cdot-$ & No & . & \\
\hline Missouri & Dept. Conserv. & No & Yes & -- & & & $\begin{array}{l}\text { Some dams are } \\
\text { topped, allowing } \\
\text { upstream movement }\end{array}$ \\
\hline Onio & Dept. Res. Mgmt. & No & $\begin{array}{l}\text { Yes } \\
\text { (limited) }\end{array}$ & $\because$ & . & & $\begin{array}{l}\text { Opposed to further } \\
\text { development }\end{array}$ \\
\hline Tenriessee & $\begin{array}{l}\text { Dept. Forestry } \\
\text { Wilda \& Fish } \\
\text { (U. of Tennessee) }\end{array}$ & No & No & $\begin{array}{l}\text { Use navigation } \\
\text { locks }\end{array}$ & No. & . & $\begin{array}{l}\text { Catadromous eels } \\
\text { have been elimi- } \\
\text { nated by dams }\end{array}$ \\
\hline
\end{tabular}

NC $=$ No Conment. 
The remainder of this section presents general information on life history and distribution of several fish species or groups that may require passage around dams at small scale hydroelectric sites in the United States. The information in these summaries was drawn from Bell (1973), Calhoun (1966), Jordan (1969), Trautman (1957), and the U.S. Department of Interior (1949).

\section{Pacific Salmon and Steelhead Trout}

The five species of Pacific salmon and the steelhead trnut are indigenous to the Pacific coastal states, British Columbia, and Alaska. Early attempts at introducing Pacific salmon to East coast streams were not successful. In recent years, however, the silver salmon (Oncorhynchus kisutch) and chinook salmon (Oncorhynchus tschawytscha) have been successfully introduced in the Great Lakes area, and spawning runs have been established.

The largest of the Pacific salmon species, the chinook or king (Oncorhynchus tschawytscha), is found from central California to Alaska and across the Bering Sea to Japan. Reproduction occurs mainly in large river systems such as the Columbia, Klamath, and Sacramento.

The silver salmon (Oncorhynchus kisutch) also has a wide range, but occurs in greatest abundance in rivers from southern Oregon to southeastern. Alaska.

The sockeye or red salmon (Oncorhynchus nerka) has a range that extends from the Columhia River to Bristol Bay, Alaska, but it is found predominantly in streams north of Puget Sound, particularly in the Fraser River in British Columbia. This species is exacting in its environmental reproductive requirements, spawning only in headwater streams containing lakes in which the young spend at least one year befure migrating downstream to the ocean.

The pink salmon (Oncorhynchus gorbuscha) ranges from Puget Sound to the Bering Sea and along the Siberian coast. to northern Korea. A peculiarity of this species is that large runs occur in the Puget Sound area only in odd-numbered years. The center of abundance is in southeastern Alaska, where they provide the bulk of the commercial catch. 
The chum saimon (Onchorhynchus keta) ranges from the Oregon coast northward to the Bering Strait, across the Arctic Ocean, along the Siberian coast and southward to Korea and northern Japan. The chum salmon is typically a short-run species, which uses coastal streams and migrates to saltwater soon after hatching.

The steelhead trout (Salmo gairdneri) is found in coastal streams and large. river systems from northern California to Alaska, some of which support distinct spring, summer, and winter steelhead runs. The life history of different races may vary, but all races spend from 1 to 3 years in freshwater before migrating to the ocean, where they may spend several years before they reach maturity at 3 to 6 years of age.

\section{Resident Trout and Char}

Resident trout and char are well distributed throughout the continental United States, Canada, and Alaska in areas where the prevailing water temperatures are cooler than those tolerated by warmwater species (e.g., largemouth bass, catfish, and sunfish).

Artificial propagation of trout and char and transfers of fish and eggs throughout the country have led to some confusion as to the original distribution of some species. However, the rainbow and cutthroat trout populations were originally found west of the Continental Divide, whereas the Eastern Brook char (Salvelinus fontinalis) and the Atlantic Salmon (Salmo salar) were found only on the eastern seaboard, in the Great Lakes system, and in northeastern Canada.

The brown trout (Salmo trutta) thrives in warmer water than the other species, and its range extends farther south. Originally imported from Germany, this species is still often referred to as the German brown trout. In some areas it has become mixed with another closely related import, the Loch Leven trout. (Salmo fario) from the British Isles.

The Dolly Varden char (Salvelinus malma) is well distributed throughout streams and lakes of the Pacific Coast, Canada, and Alaska. The 
Dolly Varden and other char characteristically spawn in the fall months, whereas trout of the genus Salmo (except the brown trout and the Atlantic salmon) spawn in the spring.

The lake char, or Mackinaw (Salvelinus namaycush), is a native of the Great Lakes area of the United States and many large lakes in interior British Columbia, other Canadian provinces, and Alask.a. It is found only in large; deep, cold-water lakes, and it has been introduced into some lakes of this type on the Pacific Coast from northern California northward.

American Shad

The American shad (Alosa sapidissima) is indigenous to the Atlantic coastal states and Canada, from Newfoundland to Florida. It has been introduced successfully into the Sacramento River in California and the Columbia River in Oregon. The Pacific range is now from Southern California to Alaska.

American shad spend most of their lives in the ocean, ascending rivers to spawn (usudlly in May and June) when the water temperature is 13.4 to $19.0^{\circ} \mathrm{C}$ ( 56 to $66^{\circ} \mathrm{F}$ ). Males precede females on the spawning migration. Eggs are released freely into the wat.er and develop in the current, hatching in 7 to 10 days. Musl American shad mature at 3 to 4 years of age, but most die after spawning. American shad average 25.4 to $33.0 \mathrm{~cm}$ (10 to $33 \mathrm{in}$.) in length and 0.9 to $2.7 \mathrm{~kg}$ (2 to $6 \mathrm{lb}$ ) in weight at maturity.

\section{Striped Bas3}

The striped bass (Morone saxatilis) is rlosely related to thr white bass; both are members of the temperate-bass family (Percichthyidae).

The original range of the striped bass was from the St. Lawrence River in Canada southward (coastal) to Louisiana. Although known principally as an anadromous species, they also thrive, but may not reproduce, in a suitable land-locked environment. The striped bass has been 
introduced successfully into many areas, such as California and the southeast, and has spread to Oregon and Washington as a result of California introductions. A large land-locked population developed in the Santee-Cooper reservoir in South Carolina from sea runs isolated within the impoundment. This has led to their introduction into other large reservoirs, which has been very successful in those cases where suitable forage fish such as threadfin shad were abundant.

Although land-locked individuals do not attain the size of the sea. run individuals, under favorable conditions they often average $2.7 \mathrm{~kg}$ (6 lb) in weight, with fish over $22.7 \mathrm{~kg}$ (50 lb) having been taken in reservoirs.

The adult striped bass move upstream from the sea, large lakes, and reservoirs in the spring to spawn in large headwater rivers. Spawning usually begins, often in May or June, when the water reaches $15.5^{\circ} \mathrm{C}$ $\left(60^{\circ} \mathrm{F}\right)$. Water current is an important factor since the semibuoyant demersal eggs are broadcast and must be kept in constant motion and off the river bottom.

Striped bass are adaptable to varied water conditions, thrive in fresh, brackish, or salt water, and tolerate both cold Canadian rivers and warm Louisiana bayous. Nevertheless, they do require suitable migration passageways to spawning areas, as well as passage downstream for juveniles after a period of stream residence. An adequate supply of a suitable forage fish is equally important.

\section{White Bass}

The white bass (Morone chrysops) belongs to the temperate basses (Percichthyidae) and is closely related to the striped bass.

The range of the white bass extends from Canada throughout the. Mississippi River drainage, from Minnesota and Wisconsin to the Gulf of Mexico. The white bass occurs in Gulf coastal rivers from Mississippi to northern Mexico and is distributed through the Great Lakes, except for Lake Superior, and eastward into the St. Lawrence River Basin. It 
also has been introduced successfully into many lakes, reservoirs, and some of the larger rivers in the eastern, midwestern, and southwestern United States and in California.

Although primarily a fish of large lakes and reservoirs, white bass also do well in large rivers. In many river systems, it is an important species in reservoir tailwaters, where populations often depend on downstream emigration from reservoirs. White bass often migrate out of reservoirs in large numbers, and therefore, adequate fish passage facilities may be necessary.

Lakes and reservoirs that have significant populations of white bass also must have adequate populations of forage fish and access to suitable spawning streams.

White bass spawn from April through June in water temperatures ranging from 14.6 to $24.1^{\circ} \mathrm{C}$ (58 to $75^{\circ} \mathrm{F}$ ). Spawning occurs in tributary streams over sand, gravel, or rocky areas. The eggs are fertilized as they sink, and as they are adhesive, they stick to gravel, rock; and vegetation. As soon as spawning is completed, the fish return to deeper water.

White bass are very prolific and often dominate the fish population in an impoundment a few years after their introduction.

\section{Smallmouth Black Bass}

The life histories of the smallmouth and the largemouth bass are similar, except that the smallmouth bass (Micropterus dolomieu) prefers a running water habitat. Smallmouth bass adults average under $1.3 \mathrm{~kg}$ ( 3 lb) in weight, but fish weighing 2.7 to $3.6 \mathrm{~kg}$ ( 6 to. $8 \mathrm{lb}$ ) have been reported. The smallmouth bass is less adaptable to turbid water conditions and is more likely to migrate in search of clear, more rapidly running water. Its habitat preference is clear, moderately cold, swiftflowing streams and moderately sized, clear-water lakes, with clean gravel or rocky bottoms.

The natural : range of the smallmouth bass is from the Upper Mississippi River drainage north and east to Quebec and southward to northern 
Alabama and eastern $0 \mathrm{klahoma.} \mathrm{It} \mathrm{has} \mathrm{been} \mathrm{introduced} \mathrm{into} \mathrm{many} \mathrm{other}$ waters, such as the Lower Snake River, and into areas in California, but it generally has not been established as successfully as the largemouth bass.

Because the smallmouth bass tends to prefer deeper waters than the largemouth, it descends to such depths during the winter months where it remains inactive. Eggs of the smallmouth bass are even more vulnerable to sudden drops in water temperature than those of the largemouth bass. Consequently, the first spawn is often killed, and a second or third spawning occurs, sometimes as late as August. Because reproduction of the smallmouth is more vulnerable to changes in the aquatic habitat, and because the smallmouth is more demanding in its selection of suitable spawning conditions, facilitating both upstream and downstream movement via passage structures may be necessary.

Smallmouth bass thrive in fairly large, rapid streams at low elevation that are too warm for salmonids. They tend to inhabit lakes in the northern part and streams in the southern part of their range. In some large reservoirs they are found along with populations of largemouth bass.

\section{Largemouth. Black Bass}

The largemouth black bass (Micropterus salmoides) is native to lakes in the eastern, central, and southern United States, as well as eastern and central Canada. Because of its great popularity as a gamefish, the largemouth black bass has been introduced into lakes and reservoirs throughout the country and has proved to be very adaptable to changing environmental conditions. This adaptability has resulted in various strains or races, such as the large, fast-growing, Florida bass. The preferred habitat is shallow, warm lakes and reservoirs, although it is also found in sluggish streams, lagoons, bayous, and brackish waters along the southern coast.

Black basses have a high reproductive capacity. Their life histories are similar, except that the smallmouth prefers a stream or 
running water habitat. Largemouth bass spawn in spring or summer when the water temperature reaches 15.7 to $20.2^{\circ} \mathrm{C}\left(60\right.$ to $\left.68^{\circ} \mathrm{F}\right)$. The male constructs and guards the nest. The female will lay from 4400 to 15,600 eggs per kilogram (2000 to 7000 per pound) of fish and, after a few days, may mate with the same or another male and spawn again over the same nest. The male also may mate again with the same or another female. After spawning occurs, the male guards the nest and cares for the eggs until hatching, which occurs in 3 to 6 days. The young remain in schools throughout their first season. Maturity is reached in the second or third year in the northern states and as early as the first year in the southerin stales. Ihe average weight of larqemouth bass is 0.9 t.n $2.7 \mathrm{~kg}$ ( 2 to $6 \mathrm{lb}$ ), but under optimum growth conditions, they may reach over $9.1 \mathrm{~kg}$ (20 1b).

The critical periods in the reproduction of both species of black bass are in the spawning and nesting stages. Abnormal changes in water temperature will kill the eggs, and water-level fluctuations destroy nests.

The largemouth bass prefers warmer water than does the smallmouth and is more adaptable to turbid water and silt. Both species are carnivorous and depend on an adequate food supply of forage fish, srayfish, other crustaceans, or amphibians. Young bass consume large numbers of aquatic insects.

Although the search for food is a primary motivation, movement of largemouth bass over dams (both upstream and downstream) may also be a response to an overcrowded habitat, unfavorable water temperatures, or the need for suitable spawning areas. Overcrowding, lack of freshwater inflow, and sparse aquatic vegetation may result in insufficient concentration of dissolved oxygen and deterioration of water quality, which in turn may influence migration.

\section{Spotted Bass}

The spotted bass (Micropterus punctulatus) may be divided taxonomically into three slightly different subspecies: the northern spotted 
bass, the Wichita spotted bass, and the Alabama spotted bass. All three have. similar life histories.

The spotted bass is mainly a stream fish, and although it is adaptable to large lakes and reservoirs, it prefers moderate to large streams of low gradient. When the water temperature reaches $10.1^{\circ} \mathrm{C}\left(50^{\circ} \mathrm{F}\right)$ in the spring, spotted bass move upstream into smaller, sluggish streams. In early summer, the adults and most of the young drift downstream. Soon after spawning, the adults move into deep water; they have been taken in reservoirs at depths of over $30.5 \mathrm{~m}(100 \mathrm{ft})$. They do not tolerate as much heat or turbidity as largemouth bass.

Spotted bass are nest builders, spawning in spring at a water temperature of $17.9^{\circ} \mathrm{C}\left(64^{\circ} \mathrm{F}\right)$. Their spawning behavior is similar to that of the smallmouth bass. Maturity generally occurs in the second or third year.

The spotted bass is indigenous to suitable rivers in many southern, midwestern, and eastern states--Florida, Alabama, Arkansas, Georgia, Illinois, Indiana, Kansas, Kentucky, Louisiana, Mississippi, Ohio, Oklahoma, Tennessee, Texas, Virginia, and West Virginia. It has been introduced into other areas such as California, where it was hatcherypropagated and where populations were established in several rivers.

Since the life history of the spotted bass includes a definite spring upstream spawning migration and a later downstream return to deeper water, it may be desirable to provide adequate upstream and downstream passage facilities.

\section{Redeye Bass}

The redeye or coosa bass (Micropterus coosae), the smallest of the bass, is found in sluggish streams that are too cold for other warmwater fish and not suitable for trout.

The original range of the coosa bass was mainly the southern states of Alabama, Georgia, Tennessee, Florida, South Carolina, and North Carolina; however, it has been introduced into several other states 
including California, in order to provide a gamefish in mid-elevation, mid-temperature streams that formerly maintained populations of rough fish only.

Redeye or coosa bass move upstream in the early spring and downstream in the fall. They spawn in coarse gravel at the heads of pools from late May to early Ju7y, in water temperatures of 16.8 to $20.7^{\circ} \mathrm{C}$ $\left(62\right.$ to $\left.69^{\circ} \mathrm{F}\right)$. They usually mature in their fourth year at a length of about $12.7 \mathrm{~cm}$ (5 in.).

The coosa bass is not suited to successful pond culture. It does not compete successfully with other predatory fish, and it does not máintain a suitable balance with sunfish or nther forage species.

To maintain a natural population of coosa bass in waters not suitable for other gamefish, provisions for unrestricted upstream and downstream passage may be necessary.

Rock Bass

The rock bass (Ambloplites rupestris) is widely distributed from southern Canada southward in the Mississippi drainage to North Carolina and the northern part of Arkansas and northward to Vermont and New York. It is common in lakes and clear streams throughout most of Minnesota, Wisconsin, Ohio and neighboring states and as far south as Louisiana and Texas. It is primarily found in rocky streams, but is also common in many lakes of moderate size. The average size for rock bass is 15.2 to $20.3 \mathrm{~cm}$ ( 6 to $8 \mathrm{in.}$ ), and the average woight is $0.2 \mathrm{~kg}(0.5 \mathrm{lb})$, although they may weigh to up to $0.9 \mathrm{~kg}$ (2 lb).

The rock bass spawns on gravel streambed or shallow, sandy lake bottoms from late May until early July at. water temperatures of 15.7 to $21.3^{\circ} \mathrm{C}\left(60\right.$ to $\left.70^{\circ} \mathrm{F}\right)$. It. is commonly fourd in the same waters as smallmouth bass. The rock bass is found mainly in clear streams of moderate size and gradient, and over streambeds of boulders, gravel, or bedrock. There is no distinct mass upstream spawning migration in the spring, although adult females may congregate in pools during the spawning season. Rock bass was formerly of commercial importance in the island region of western Lake Erie. 
Crappie

The life histories of the two species of crappie--the black crappie (Pomoxis nigromaculatus) and the white crappie (Pomoxis annularis)--are quite similar. Both are found in quiet waters of lakes, ponds, reservoirs, and slow-moving streams, usually where there is a good growth of aquatic vegetation. Both are considered predatory species, feeding mainly on aquatic insects and small fish, and are frequently found in large schools. They are nest builders, constructing nests, in water from. 0.9 to $1.8 \mathrm{~m}$ ( 3 to $6 \mathrm{ft}$ ) deep on sandy or silted bottoms, among rooted aquatic plants. They spawn in late spring or early summer--the black crappie in water temperatures of 14.6 to $17.9^{\circ} \mathrm{C}$ (58 to $64^{\circ} \mathrm{F}$ ) and the white crappie in water temperatures of 17.9 to $20.2^{\circ} \mathrm{C}$ ( 64 to $68^{\circ} \mathrm{F}$ ). Black crappie prefer clear water, and white crappie can tolerate more turbid water conditions, although both species are found in some clear lakes and in many turbid lakes and reservoirs. Black crappie tolerate cooler water temperatures and are found farther north than the white crappie.

Both species are indigenous to waters east of the Rocky Mountains, although both have been introduced into suitable waters throughout the United States and Canada.

Normally both species mature at 2 to 3 years of age at a length of 17.8 to $20.3 \mathrm{~cm}$ ( 7 to 8 in.), although under optimum conditions, they often attain a length of about $30 \mathrm{~cm}$ (12 in.) and a weight of 0.4 to $0.9 \mathrm{~kg}$ (1 to $2 \mathrm{lb})$.

Crappie show little inclination to migrate under normal water conditions, but will extend their habitat into available suitable waters when conditions are desirable.

\section{Yellow Perch}

The yellow perch (Perca flavescens) is abundant in lakes, reservoirs, and slow-moving large streams throughout southern Canada, the midwestern and eastern states, and has been widely introduced elsewhere. Perch are very hardy and prolific and, under favorable conditions, tend 
to overpopulate the body of water. The results are stunted perch and detrimental effects on the other species with which they compete for food and living space. Perch are entirely carnivorous, eating minnows, the young of other fishes, small amphibians, mollusks and crustaceans, and aquatic insects.

Most of the perch taken by anglers are 12.7 to $20.3 \mathrm{~cm}$ ( 5 to 8 in.) in length, although fish up to $30: 5 \mathrm{~cm}$ (12 in.) in length and about $0.2 \mathrm{~kg}(0.5 \mathrm{lb})$ in weight are caught.

Spawning occurs in the spring at water temperatures of 7.3 to $12.9^{\circ} \mathrm{C}$ $\left(45\right.$ to $55^{\circ} \mathrm{F}$ ), in areas near shores and around aquatic plants or hrush. The eggs are laid in a sellibuuyant, nonadhesive, gelatimous string. There is no parental care. The eggs, hatch. in 3 to 4 weeks, and the young generaliy school. Maturity is reached at about 2 years of age.

Schools of perch often, but not always, leave their lake or reservoir habitat during the spring spawning season and ascend tributary streams. They will successfully populate any suitable waters that are accessible to them. The yellow perch is a valuable forage fish for many larger-sized gamefish in large lakes and reservoirs. A valued food fish, the yellow perch is also of considerable commercial importance in the lireat Lakes area.

\section{Sunfish}

There are many species of sunfish, or bream, as they are frequently called. The most common sunfish are here considered as a grnup herause their life histories are very similar. These are the bluegill (Lepomis macrochirus), the pumpkinseed (Lepomis gibbosus), the green sunfish (Lepomis cyanellus), the long-eared sunfish (Lepomis megalotis), and the shell cracker (Eupomotis holbrooki).

The sunfish comprise the must popular and widespread panfish in the sport fishery. The bluegill, particularly, is important as a forage fish for the largemouth bass populations in both private and commercial farm and ranch ponds. 
The sunfish ranges from southern Canada to the Gulf states; throughout the Mississippi Valley and the eastern and southern states. The bluegill has been introduced wherever bass fisheries are maintained. Since all the sunfish are quite prolific, a common problem in ponds is overpopulation. All the sunfish are nest builders, with the male building and guarding the nest. The spawning season extends from May through Juily, and under favorable water conditions, spawning occurs repeatedly throughout the summer. Although the average size of most species is 17.9 to $20.3 \mathrm{~cm}$ ( 7 to 8 in.), some sunfish may attain a length of 30.5 $\mathrm{cm}$ (12 in.) and a weight of more than $0.4 \mathrm{~kg}(1 \mathrm{lb})$.

Although primarily warmwater lake and pond fish, sunfish also are found in many slow-moving warmwater streams. They are quite hardy and adaptable to suboptimal water conditions. Water temperatures between 15.6 and $26.9^{\circ} \mathrm{C}\left(60\right.$ and $\left.80^{\circ} \mathrm{F}\right)$ are best for growth and reproduction. The preferred foods are zooplankton, aquatic insects, and any other small organisms.

Under normal water conditions, sunfish do not migrate, either. upstream or downstream. Optimum conditions, however, often lead to overcrowding, particularly with the prolific bluegill, and unless a suitable predator-prey relationship is maintained, the population naturally will attempt to expand into a less crowded area.

\section{Catfish}

About 35 species of catfish occur in waters of Canada, the United States, and Mexico, of which none are indigenous to the Pacific coast. Only the better known species of importance to the sport or commercial fisheries are considered here.

The catfish family (Ictaluridae) may be divided for convenience into two groups: (1) the common bullhead, consisting of three species (the yellow, brown, and black bullheads), and (2) the channel catfish (Ictalurus punctatus), a favorite warmwater gamefish and the best known of a number of larger, more popular species. The average length of 
bulthead catfish is 15.2 to $20.3 \mathrm{~cm}$ ( 6 to $8 \mathrm{in.}$ ). The bullheads are very hardy and prolific and adaptable to a wide variety of conditions, including very muddy water. They present no migration problems.

Channel catfish primarily inhabit moderate to swiftly flowing streams, but may also be found in some sluggish streams and in many warmwater lakes and reservoirs. Channel catfish usually are found in clearwater streams in water temperatures over $21.3^{\circ} \mathrm{C}\left(70^{\circ} \mathrm{F}\right)$. Channel catfish usually move downstream in the fall, probably in search of warmer water. Spawning occurs in early summer, when the water temperature reaches about $24.1^{\circ} \mathrm{C}\left(75^{\circ} \mathrm{F}\right)$. They usually mature at a length of 25.4 to $10.6 \mathrm{~cm}$ (10 to $16 \mathrm{in}$ ) and at more than 5 years of age. Tliey llidy attain a length of more than $0.9 \mathrm{~m}(3 \mathrm{ft})$ and a weight of about 11.2 $\operatorname{kg}(251 \mathrm{~b})$.

The indigenous range of channel catfish extends from the southern portions of the Canadian prairie provinces southward through the Great Lakes and Mississippi Valley to the Gulf states and Mexico. They do not occur on the Atlantic coastal plain. They have been widely introduced into many areas in the midwest, south, west, and southwest. They are cultured in warmwater hatcheries and grown commercially in flooded rice fields in Arkansas, Louisiana, and Texas. They constitute an important commercial catch in many parts of the south and southwest.

Channel catfish are rather specific in their spawning area requirements, seeking secluded, well-hidden areas with moving water at temperatures above $21.3^{\circ} \mathrm{C}\left(70^{\circ} \mathrm{F}\right)$, and optimum temperatures of about $26.9^{\circ} \mathrm{C}$ $\left(80^{\circ} \mathrm{F}\right)$. Provision for unrestricted passage, both upstream and downstream is often necessary, particularly during the spawning season, which often occurs from late May through mid-July.

\section{Blue Catfịsh}

The blue catfish (Ictalurus furcatus) is the largest American catfish. It may attain a length of $1.8 \mathrm{~m}(6 \mathrm{ft})$ and a weight of over $67.5 \mathrm{~kg}$ (150 1b). The blue catfish is found in the deeper waters of the Mississippi River and its larger tributaries, from Minneapoli.s southward. 
Its range is from Kansas and Minnesota, eastward through the Ohio Valley and southward to the Gulf of Mexico and northeastern Mexico. The blue catfish, which exhibits migratory habits, is found most often in the upper Mississippi during the summer months, when the water is warmest, moving south with the advent of cold weather. It is frequently taken during the summer months from Lake Pepin and southward in the Mississippi River.

Because of its definite migratory habit, the blue catfish may require unobstructed passage both upstream and downstream on major rivers in the Mississippi River system.

\section{Flathead or Shovelhead Catfish}

The flathead or shovelhead catfish (Pylodictis olivaris) is a large catfish that attains a length of $1.5 \mathrm{~m}(5 \mathrm{ft})$ and weight of $45 \mathrm{~kg}$ (100 1b). Weights of more than $18 \mathrm{~kg}(40 \mathrm{lb})$ are common. It has a slender body and a large, broad, depressed head. : It is found in Lake St. Croix and is common in the Mississippi River drainage below St. Paul. It inhabits lakes and large, sluggish rivers and is mostly confined to the larger tributaries of the Mississippi. It is found in Lake Pepin, but not as abundantly as the blue catfish. It is very abundant in the lower Mississippi Valley, where it is often taken commercially. It is most abundant in Arkansas, west Tennessee, and Louisiana.

\section{Walleye}

The walleye (Stizostedion vitreum) is the largest member of the perch family. Walleye may attain a maximum length of $0.9 \mathrm{~m}(3 \mathrm{ft})$ and a weight of over $11 \mathrm{~kg}$ (25 lb). A voracious predator, the walleye feeds primarily on fish, but also on aquatic insects.

The indigenous range of the walleye extends from the Great siave Lake in Canada, the Saskatchewan river system, the Hudson Bay region and Labrador, southward through the Mississippi River system and Atlantic slope drainage to North Carolina, and westward to the Alabama River 
system of Georgia, the Tennessee River drainage of Alabama, and northern Arkansas and Nebraska. It is also abundant in large, clean, cold lakes of the Mississippi headwaters. The walleye is adaptable to a wide variety of habitat and has been introduced into many western waters, as in California, with varied success.

Walleye are found mainly in larqe lakes, reservoirs, and streams. They prefer clear water over gravel, bedrock, or other firm bottoms. They are not often found in shallow, heavily vegetated areas. Although they prefer a summer maximum water temperature of $25.2^{\circ} \mathrm{C}\left(77^{\circ} \mathrm{F}\right)$, sustained populations occur in waters ranging from 0 to $32.5^{\circ} \mathrm{C}\left(32\right.$ to $90^{\circ} \mathrm{F}$ ).

Walleye spawn from Marcli to June, when water temperature is 3.4 to $10.1^{\circ} \mathrm{C}$ ( 38 to $50^{\circ} \mathrm{F}$ ), with optimum spawning temperatures being 7.3 to $10^{\circ} \mathrm{C}\left(48\right.$ to $50^{\circ} \mathrm{F}$ ). The eggs are broadcast in water 30 to $76 \mathrm{~cm}$ deep over gravel riffles or rocky shoals. In the spring, some walleye migrate up tributary streams from lakes and reservoirs to spawn, whereas others may spawn in the lake or reservoir. Males usually mature at 4 years of age, and females mature at 5 years.

The fact that the walleye is adaptable to a wide range of water temperatures, including cooler waters, encourages its spread into adjacent waters, wherever such migration is possible. It is accepted as a valuable part of the sport and commercial food fishery.

The average size of walleyc is from 0.4 to $1.8 \mathrm{~kg}$ (1 to 4 b).

\section{sauger}

The sauger (Stizostedion ranadense) is quite similar to the walleye; the two are often confused. The average size of the sauger is less than that of the walleye, usually not more than 30.4 to $45.7 \mathrm{~cm}$ (12 to $18 \mathrm{in.}$ ) in length and 0.4 to $0.9 \mathrm{~kg}$ ( 1 to $2 \mathrm{lb}$ ) in weight.

The range of the sauger is from the $S t$. Lawrence River westward through the Great Lakes and in the Mississippi Valley west to Montana and south to Tennessee, Arkansas, northern Alabama, and West Virginia. It commonly occurs throughout the Ohio River and Lake Erie watersheds. In Canada the sauger is found in the St. Lawrence River Basin, the 
Canadian portions of the Great Lakes, throughout Ontario, and northward to the Hudson Bay watershed. It formerly reached its greatest abundance in Lake Erie. It is often quite abundant in shallow inland lakes, but also inhabits large, sluggish rivers.

The life history of the sauger is similar to that of the walleye, except that it grows more slowly than the walleye. The eggs are deposited in shallow water in the spring. Like the walleye, the sauger is carnivorous, mainly eating small fish found close to the bottom and aquatic insects. The sauger is taken in both sport and commercial fisheries. Sauger, because they are more tolerant of turbid water and silted bottom than the walleye are often more abundant under such unfavorable conditions.

Sauger have no definite migration requirements other than the spring movement to suitable spawning areas.

\section{Cisco and Whitefish}

The most common species of cisco, or lake herring, is (Coregonus artedii). The lake herring is most abundant in the Great Lakes and Lake Huron. Coregonus artedi i averages 27.9 to $38.1 \mathrm{~cm}$ (11 to $15 \mathrm{in}$.) in length and weights from 0.2 to $0.7 \mathrm{~kg}$ ( 9 oz to 1 lb $4 \mathrm{oz}$ ).

The life histories of the lake herring and related species are similar. They spend most of their life in the deeper portion of the Great Lakes. However, in the spring, when shoal waters become warmer, they move toward shore, apparently in search of food. In the fall they migrate shoreward to spawn. Spawning occurs chiefly in November.

of the many species of whitefish, the best known are probably the common lake whitefish (Coregonus clupeaformis), common in all the Great Lakes, and the mountain whitefish (Prosopium williamsoni), which occurs in all suitable waters from the west slope of the Rocky Mountains to the Pacific Ocean and from British Culumbia to Utah.

The lake whitefish averages 43.2 to $55.9 \mathrm{~cm}$ (17 to $22 \mathrm{in.}$ ) in length and 0.7 to $1.8 \mathrm{~kg}(1.5$ to $4.0 \mathrm{lb})$ in weight. 
The mountain whitefish usually is 17.8 to $25.4 \mathrm{~cm}$ ( 7 to $10 \mathrm{in.}$ ) in length, but may attain a length of over $30.5 \mathrm{~cm}$ (12 in.) and a weight of about $1.8 \mathrm{~kg}$ (4 1b). The mountain whitefish prefers cold, clear lakes, but is also found in many streams.

The life histories of all whitefish species are similar. Those found in lakes remain in deep water except during spawning season, which occurs in late fall or early winter, at which time they ascend tributary streams.

Other Species of Possible Concern and Qualifying Remarks

- The selection of species discussed in this section is not intended to eliminate from consideration other species that may require passage. The species discussed provide a broad range of life history and spawning requirements that should be useful general information for early scoping of the fish passage issue. The presence of endangered species (e.g., the shortnose sturgeon) at a site may require special consideration. Other species (e.g., mullet, American eel, northern pike, smelt, landlocked salmon, blueback herring, alewives), although not discussed, may be of concern on a site-specific basis.

Another factor, beyond the scope of this report, deserves note. Passage of nontarget species upstream around dams (including "pest" species such as the sea lamprey or "undesirable" species). along with passage of the species of concern should be evaluated on a site-specific basis. Passage of nontarqet species may adversely impart upstream aquatic systems if this possibility is not evaluated. 
Be11, M.C. 1973. Fisheries Handbook of Engineering Requirements and Biological Criteria. Fisheries Engineering Research Program, U.S. Army Corps of Engineers, North Pacific Division, Portland, Oregon.

Calhoun, A. (ed.). 1966. Inland Fisheries Management. California Department of Fish and Game, Sacramento, California. $546 \mathrm{pp}$.

Jordan, D.S. 1969. American Food and Game Fishes. Dover Publications, Inc., New York.

Trautman, M.B. 1957. The Fishes of Ohio. The Ohio State University Press, in collaboration with the Ohio Division of Wildlife and the Ohio State University Development Fund, Waverly Press, Inc., Baltimore, Maryland.

U.S. Department of Interior, Fish and Wildlife Service. 1949. Pacific salmon. Fishery Leaflet No. 14, Washington, D.C. 


\section{THIS PAGE}

\section{WAS INTENTIONALLY LEFT BLANK}




\section{SOME BIOLOGICAL FACTORS RELATED TO UPSTREAM}

FISH PASSAGE AROUND DAMS

by

James J. Anderson

Section 3 reviews studies on biological factors related to the successful upstream passage of fish around dams. The topics covered include gas bubble disease; fish swimming. speed as related to length, temperature, oxygen, and toxic substances; oxygen consumption as related to weight, temperature, swimming speed, and toxic substances; schooling behavior; and diel and photo behavior. This section provides background information for the design criteria discussed in Section 5.

\subsection{Gas Bubble Disease}

Water that is supersaturated with dissolved gases can adversely affect fish and other aquatic organisms. Called gas bubble disease, this effect is manifested as bubbles forming within the organism.

Fish can tolerate exposures to water of up to $110 \%$ supersaturation without significant effects, but significant mortality can occur at values of about $115 \%$ (Table 2).

Fish can escape the effects of supersaturation by sounding into deeper water, where the percent saturation is lower as a result of the increased gas solubility with increased pressure. The relationship between percent saturation, temperature, and depth can be approximated by the formula,

$$
\% \operatorname{Sat}(T, Z)=\left[\frac{1-0.006 \mathrm{e}^{0.06 T}}{1-0.006 \mathrm{e}^{0.06 \mathrm{~T}_{S}}}\right] \frac{\% \operatorname{Sat}\left(T_{S}, 0\right)}{1+0.1 Z}
$$


Table 2. Comparative sensitivity of juvenile and adult salmonids and bass to air-supersaturated water

\begin{tabular}{lc}
\hline \multicolumn{1}{c}{ Fish } & Threshold $\left(\frac{9}{\text { sal. })^{\text {a }}}\right.$ \\
\hline Sockeye smolts & $113.6 \%$ \\
Juvenile steelhead & 113.8 \\
Juvenile sockeye & 114.0 \\
Ndult sockeye & 114.2 \\
Steelhead smolts & 114.2 \\
Aulult culiu & 114.4 \\
Adult steelhead & 114.6 \\
Adult chinook & 114.7 \\
Coho smolts & 114.8 \\
Juvenile coho & 118.0 \\
Adult bass & 126.8 \\
Juvenile bass & 128.0 \\
\hline
\end{tabular}

a Based on time to $20 \%$ mortality.

Source: Garton and Nebeker 1977. 
where

$$
\begin{aligned}
\mathrm{Z} & =\text { depth, } \mathrm{m}, \\
\mathrm{T} & =\text { temperature of the water at depth } \mathrm{Z},{ }^{\circ} \mathrm{C}, \\
\mathrm{T}_{\mathrm{S}} & =\text { temperature of the water at the surface, }{ }^{\circ} \mathrm{C}, \\
\% \text { Sat }\left(\mathrm{T}_{\mathrm{S}}, 0\right) & =\text { percent saturation value at the surface, } \\
\% \text { Sat }(\mathrm{T}, \mathrm{Z}) & =\text { percent saturation value at depth } \mathrm{Z}, \\
\mathrm{e} & =2.7183 .
\end{aligned}
$$

From the formula, water with $125 \%$ supersaturation at the surface will be $100 \%$ saturated at a depth of $2.5 \mathrm{~m}$ if $T=T_{s}$. Because temperature generally affects saturation only slightly, as compared with depth, the term in brackets can be taken to be equal to 1 .

Typical high head dams on the Columbia and Snake Rivers have produced surface supersaturations between 115 and $130 \%$ below the dam when water is released over the spillways. The major mechanism causing gas supersaturation is the entrainment of air by water as it passes over a spillway and falls into a plunge basin. Gas (primarily nitrogen) is forced into solution under pressure at depth in the plunge basin. Because water passing through the turbine produces little supersaturation, a first approximation is that gas bubble disease at small scale dams is likely to be insignificant. The depth that spillway water reaches in a basin below a typical small scale hydroelectric dam most likely will not cause gas supersaturation.

\subsection{Fish Swimming Speed}

Fish swimming has been described in terms of several levels of activity, which in order of decreasing speed are burst, steady, critical, and sustained swimming speeds.

Burst activity, $S_{b}$, which can be maintained only for a few seconds, is independent of the water temperature and oxygen content, but is dependent on fish length $x$. The relation can be approximated by

$$
S_{b}=a x^{c}
$$


The terms $a$ and $c$ are fitted constants from a regression equation.

Bainbridge (1961) fit data on dace, goldfish, trout, barracuda, porpoise, and dolphin to the linearized form of Equation (2): $\ln S_{b}=c \ln x+\ln a$. The resulting constants are $a=14.8 / \mathrm{s}$ and $c=0.88$, where $X$ is given in centimeters, and $S_{b}$ is given in centimeters per second (Bainbridge 1961).

The sustained speed, which can be maintained indefinitely, requires a balance between the intake and use of energy in the form of carbohydrates and protein. Generally, the sustained speed is about one to three body lengths per second (Brett 1964).

The steady speed, which is between the burst and sustained speeds, can be maintained for periods ranging from a few minutes to a few hours. This activity depends on the oxygen content and temperature of the water. The maximum speed in the steady speed range is the critical speed $\left(S_{c}\right)$, and the metabolic level associated with the critical speed is called the active metabolism by Brett (1964).

The critical swimming speed $\left(S_{C}\right)$, which is a function of fish length (X) (Brett 1964, Brett 1967, and Brett and Glass 1973), can be expressed by

$$
S_{C}=s_{0} x^{h}
$$

where $S_{C}$ is generally expressed in centimeters per second, $X$ is expressed in centimeters, $S_{0}$ is the critical speed when $X=1 \mathrm{~cm}$, and $b$ is a regression coefficient (dimensionless). The exponent. $h$ is hetwoon 0.5 and 0.7 , arul dll uverall average suggested in a review by Wu and Yates (1978) is $h=0.6$.

Ihe temperature dependence of the critical swimming speed for sockeye salmon has an exponential form when oxygon is ahundant (Brell and Glass 1973). Thus, for a fish of a given size,

$$
S_{c}=S_{0, T^{e}}{ }^{a T}
$$


where

$$
\begin{aligned}
\mathrm{T} & =\text { temperature, }{ }^{\circ} \mathrm{C}, \\
\mathrm{S}_{\mathrm{o}, \mathrm{t}} & =\text { swimming speed at } \mathrm{T}=0^{\circ} \mathrm{C}, \mathrm{cm} / \mathrm{s}, \\
\mathrm{a} & =\text { a regression coefficient }\left(\frac{1}{{ }^{\circ} \mathrm{C}}\right) .
\end{aligned}
$$

By reading graphical data from Figure 4 in Brett and Glass (1973) for temperatures between 0 and $15^{\circ} \mathrm{C}$ and fitting this data to $\mathrm{Eq}$. (4), an estimate of $\mathrm{S}_{0}=7.4 \mathrm{~cm} / \mathrm{s}$ and $\mathrm{a}=0.04$ is obtained. At higher temperatures, oxygen concentration at saturation is lower, and the fish cannot meet their oxygen demand; consequently, the critical speed decreases.

Davis et al. (1963) determined the relationship between critical speed and oxygen for juvenile coho and chinook salmon. Generaliy, the swimming speed decreased in a hyperbolic manner for oxygen concentrations below the air-saturation level. The response can be described by.

$$
S_{c}=s_{0,0_{2}}\left(\frac{0_{2}}{0_{2}+k}\right)
$$

where

$$
\begin{aligned}
& 0_{2}=\text { oxygen concentration, mg/liter, } \\
& \mathrm{S}_{\mathrm{O}_{0} 0_{2}}=\text { critical swimming speed in air-saturated water }(\mathrm{cm} / \mathrm{s}) \text {, } \\
& k=\text { oxygen concentration when the critical speed is one-half }
\end{aligned}
$$

Toxic substances generally decrease the critical swimming speed of fish exponentially. Often a certain threshold concentration must be exceeded before the effect is evident. The magnitude and form of the response can be complicated by the many interactions between toxic substances, temperature, oxygen, $\mathrm{pH}$, salinity, life stage of the fish, and other variables. 
To describe the first-order response of a single toxic substance, the concentration of the substance is expressed as a fraction of the lethal concentration required to $k i 1150 \%$ of the fish in a prescribed length of time. If the lethal concentration is designated $\mathrm{LC}_{50}$ and the actual concentration of the substance is $C$, then the normalized concentration is

$$
P=C / L C_{50}
$$

In this manner the response of the critical swimming speed to the substance is normalized to the sensitivity of the fish to the substance. If the threshold concentration is small compared with the $L C_{50}$ concenliation, then the critical swimming speed can be approximated by

$$
s_{c}-s_{o, p} e^{c P}
$$

where

$$
\begin{aligned}
S_{0, P} & =\text { critical speed when } P=0, \\
C & =\text { rate coefficient that is dimensionless. }
\end{aligned}
$$

The effect of $P$ un the distance a fish swims to fatigue, $L_{f}$, or on the time a fish swims to fatigue, $T_{f}$, should give the same qualitative relationship as Eq. (6), if the swimming speed of the fish is maintained in the steady activity range.

Values of $c$ for severil toxtc substances range between 0 and -11 (Table 3 ). The resulting range of swimming performance for a given level of substance normalized to the lethal concentration is large, thus illustrating that the mechanisms by which varlous toxic substances affect motion are more varied than the mechanisms that induce mortality. Also, the sensitivity of a fish to a particular substance can depend on other environmental factors such as temperature and oxygen.

In summary, available information indicates that fish swimming performance can be affected by size of $\mathrm{fish}$, water temperature, oxygen 
Table 3. Effect of toxic substances on swimming performance. LC is the lethal concentration usually taken as the concentration that induces $50 \%$ mortality in $48 \mathrm{~h}$, $c$ is the coefficient in Equation (6), and $F(1 / 3)$ is the fraction of the normal swimming performance when $P=1 / 3$.

\begin{tabular}{|c|c|c|c|c|c|}
\hline $\begin{array}{c}\text { Toxic } \\
\text { substance }\end{array}$ & Species & LC & c & $F(1 / 3)$ & Reference \\
\hline $\begin{array}{l}\text { Kraft pulp } \\
\text { mill effluent }\end{array}$ & $\begin{array}{l}\text { Fingerling } \\
\text { Coho salmon }\end{array}$ & $\begin{array}{l}18 \text { to } 45 \\
\text { vol } \frac{\mathrm{o}}{\mathrm{o}}\end{array}$ & -1.8 & 0.55 & Howard (1975) \\
\hline Fenitrothion ${ }^{a}$ & Brook trout & $\begin{array}{l}1500 \mathrm{mg} / \\
\text { liter }\end{array}$ & -0.4 & 0.88 & Peterson (1974) \\
\hline Copper ${ }^{b}$ & $\begin{array}{l}\text { Rainbow } \\
\text { trout }\end{array}$ & $20 \mathrm{mg} / \mathrm{liter}$ & -0.2 & 0.94 & $\begin{array}{l}\text { Waiwood and } \\
\text { Beamish (1978) }\end{array}$ \\
\hline $\begin{array}{l}\text { Pulpwood } \\
\text { fiber }\end{array}$ & $\begin{array}{l}\text { Fathead } \\
\text { minnow }\end{array}$ & $350 \mathrm{ppm}^{\mathrm{d}}$ & -0.8 & 0.77 & $\begin{array}{l}\text { MacLeod and } \\
\text { Smith (1966) }\end{array}$ \\
\hline $\begin{array}{l}\text { Hydrogen } \\
\text { sulfide }\end{array}$ & Brook trout & $\begin{array}{l}0.021 \mathrm{mg} / \\
\text { liter }\end{array}$ & -1.0 & 0.72 & $\begin{array}{l}\text { Smith et al. } \\
(1976)\end{array}$ \\
\hline $\begin{array}{l}\text { Hydrogen } \\
\text { sulfide }\end{array}$ & $\begin{array}{l}\text { Juvenile } \\
\text { bluegill }\end{array}$ & $\begin{array}{l}0.029 \mathrm{mg} / \\
\text { liter }\end{array}$ & -3.6 & 0.30 & $\begin{array}{l}\text { Smith et al. } \\
(1976)\end{array}$ \\
\hline Cyanide & Trout & $\begin{array}{l}0.08 \mathrm{mg} / \\
\text { liter }\end{array}$ & $\begin{array}{c}-6 \text { to } \\
-11\end{array}$ & $\begin{array}{l}0.14 \\
0.03\end{array}$ & Neil (1957) \\
\hline Cyanide & Coho salmon & $\begin{array}{l}0.1 \mathrm{mg} / \\
\text { liter }^{\mathrm{f}}\end{array}$ & $\begin{array}{l}-4 \text { to } \\
-8\end{array}$ & $\begin{array}{l}0.26 \\
0.07\end{array}$ & $\begin{array}{l}\text { Broderius } \\
(1970)\end{array}$ \\
\hline Cyanide & $\begin{array}{l}\text { Juvenile } \\
\text { cichlids }\end{array}$ & $\begin{array}{l}0.13 \mathrm{mg} / \\
\text { liter }\end{array}$ & -1 & 0.72 & Leduc (1966) \\
\hline $\begin{array}{l}\text { Sodium } \\
\text { pentachloro- } \\
\text { phenate (PCP) }\end{array}$ & $\begin{array}{l}\text { Underyearling } \\
\text { sockeye } \\
\text { salmon }\end{array}$ & $63 \cdot p p m$ & . & 1.0 & $\begin{array}{l}\text { Webb and Brett } \\
(1973)\end{array}$ \\
\hline
\end{tabular}

${ }^{a}$ A herbicide.

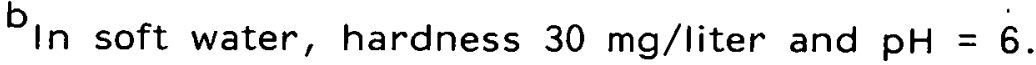

$c_{75 \%}$ spruce, $25 \%$ balsam fir.

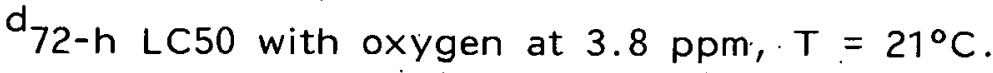

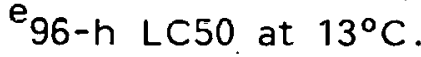

${ }^{f}$ Estimated according to trout response: 
concentration in water, and toxic elements or compounds that may be present. Awareness of these factors is necessary in the design of fish passage facilities, as emphasized in Section 5.

\subsection{Oxygen Consumption}

The consumption of oxygen by fish depends on fish weight, swimming speed, water temperature, and pollution stress. Brett and Glass (1973) examined earlier work and determined the relationship between oxygen consumption, body weight, and temperature for standard metabolism (resting fish) and active metabolism (fish swimming at the critical speed). The relationship for either metabolic level can be described by

$$
Y=Y_{0} e^{a T} W^{b}
$$

where

$$
\begin{aligned}
Y & =\text { respiration rate, } \mathrm{mg} \mathrm{O}_{2} / \mathrm{h} . \\
T & =\text { temperature, in }{ }^{\circ} \mathrm{C}, \\
W & =\text { fisll weight, in } \mathrm{g} . \\
Y_{0} & =\text { respiration rate }\left(\mathrm{mg} 0_{2} / \mathrm{h}\right) \text { at } 0^{\circ} \mathrm{C} \text { for a } 1-g \text { fish, }
\end{aligned}
$$

$a$ and $b=$ fitted ronstants.

For standard metabolism of sockeye salmon, the constants derived by fitting data from data given by Brett and Glass (1973) are $Y_{U}=0.037$

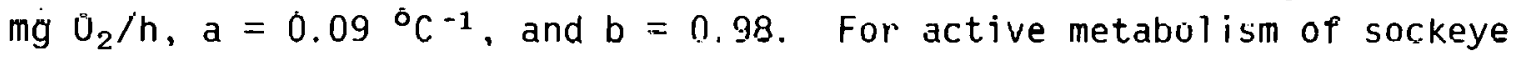
when temperature is less than with $15^{\circ} \mathrm{C}, \mathrm{Y}_{\mathrm{O}}-0.32 \mathrm{mg} 0_{2} / \mathrm{ll}, d=0.0 \%{ }^{\circ} \mathrm{C}=\mathrm{d}$, and $\mathrm{b}=0.98$. For temperatures above $15^{\circ} \mathrm{C}$, active respiration in the experimients was 1 imited by the availability of nxygen.

ihe relationship between respiration, temperature, and swimming speed between the critical speed and rest was investigated by Brett (1964). The response normalized to body weight and fish length can be described by

$$
Y^{\star}=Y_{.0}^{\star} e^{\mathrm{aU}+\mathrm{bUT}+\mathrm{cT}},
$$


where

$$
\begin{aligned}
Y^{*} & =\text { respiration, } \mathrm{mg} \mathrm{O}_{2} / \mathrm{h} \mathrm{kg}, \\
\mathrm{U} & =\text { swimming speed, body lengths } / \mathrm{s}, \\
\mathrm{T} & =\text { temperature }{ }^{\circ} \mathrm{C}, \\
Y_{0}^{*}= & \text { respiration rate in } \mathrm{mg} \mathrm{O}_{2} / \mathrm{h} \mathrm{kg} \text { when fish resting } \\
& \text { in } 0^{\circ} \mathrm{C}, \\
\mathrm{a}, \mathrm{b}, \text { and } \mathrm{c}= & \text { fitted constants. }
\end{aligned}
$$

For $18-\mathrm{cm}, 50-\mathrm{g}$ sockeye salmon, $Y_{0}^{*}=33.4 \mathrm{mg} 0_{2} / \mathrm{h} \mathrm{kg}, a=0.78 \mathrm{~s} /$ body length, $b=-0.015 \mathrm{~s} /$ body length $/{ }^{\circ} \mathrm{C}$, and $\mathrm{c}=0.065$. These constants give a reasonable fit to observations reported by Brett (1964).

The effect of toxic substances on oxygen respiration has been investigated in only a few studies. Waiwood and Beamish (1978) determined that brook trout respiration increases with increases in copper concentration and decreases in $\mathrm{pH}$ and water hardness. The combination of $\mathrm{pH}$ and hardness controls the $\mathrm{Cu}^{++}$concentration. Davis (1973) determined that respiration in sockeye salmon immediately increased with exposure to bleached Kraft pulp mill effluent. One day later, the respiration rate of fish exposed to low concentrations (20\% of $L_{50}$ ) was elevated, whereas the fish exposed to high concentrations ( $70 \%$ of $L_{50}$ ) had normal respiration rates. Crande 11 and Goodnight (1962) demonstrated that pentachlorophenate (PCP) increases respiration in common guppies. MacLeod and Smith (1966) demonstrated that metabolism decreases with increasing pulpwood fiber concentration. The contrasting results of the response of respiration to $P C P$ and wood fiber--increased respiration for PCP and decreased respiration for fiber--illustrate that toxic substances can stress the organism in various ways. Increased respiration generally results when the toxic substance produces a metabolic inefficiency, whereas decreased respiration results when the substance clogs or damages the gills.

0xygen consumption by fish may be of concern in fish passage design, especially if crowding of fish in fish locks and lifts is anticipated (see Section 4). The above analyses emphasize the need for being aware 
of the ways in which environmental variables affect respiration. Areas of concern specific to fish passage facility design are presented in Section 5 .

\subsection{Schooling Behavior}

Fish have a tendency to group together in schools, with the distance between fish proportional to the fish length (Breder 1976). A number of observations suggest that for most species schools are compact in the day and dispersed or loosened at night (Katz 1978, Stroch et al. 1978, and Squire 1978). Frull observations of anchovies, carpelins, Árctic cod, cod herring, and rock genadier, Sevebrov (1976) developed a regression between fish length, $X$, and separation distance, $L$ :

$$
L=2.4 X \text {. }
$$

Symon and Heland (1978) observed yearling salmon in streams and determined a graphical relation between fish length, $X$; and number of $f$ ish per. $100 \mathrm{~m}^{2}, \mathrm{~N}$. The relation can be expressed by the equation

$$
N=a X^{-b}
$$

From three data sets, $a=1100 \pm 600 \mathrm{fish} / \mathrm{cm}$ and $b=3.2 \pm 0.1$. From Eq. (10), for $X=10 \mathrm{~cm}, N=7$, whereas for $X=3 \mathrm{~cm}, N=326$. From this information, it appears that, as fish size increases, the separation distance between fish in schools increases, and as fish size decreases, the density of fish in schools.increases. Schooling behavior of fish may be a factor in the design of fish passage facilities, especially in determining facility dimensions. If fish tend to entor passage facilities in schools rather than individually, the structure must be able to accommodate such behavior. 


\subsection{Diel and Photo Behavior}

The diel and photo behaviors of fish are largely determined by predator-prey interactions. Because these interactions change over the lifetime of the fish, the behavior can also change. Some behavioral observations for certain fish follow.

Gizzard shad: Larvae in a flood reservoir in Central Illinois concentrated at the surface in the day and dispersed from the surface at night (Storch et al. 1978).

Walleye: Young were positively phototactic at ambient daytime illumination from hatching through postlarval stages (2.5- to $3-\mathrm{cm}$ length). After 2 years, walleye were observed to be negatively phototactic (Ryder 1977). In West Blue Lake in Canada, older (2- to 5-years) walleye moved within $100 \mathrm{~m}$ of shore and were relatively inactive during the day. Feeding occurred at dawn and dusk. Average swimming speed in the day was about 1 body length/s, and during feeding, speed increased to about 3 body lengths/s. The observations suggest that feeding activity is related to light intensity; in turbid waters, walleye feed during the day (Kelso 1978).

Perch: In West Blue Lake, old perch were inactive at night, but young perch were active in shallow water, thus becoming vulnerable to walleye predation (Kelso 1978). A 1-year study in Lake Windermere, England, indicated that perch generally migrate into deep water in the winter and throughout the year were most active at low light intensities (Craig 1977). Studies by Alabaster and Stott (1978) also found that perch are more active at dawn and dusk.

American shad: During the day shad swim in schools at speeds of about $45 \mathrm{~cm} / \mathrm{s}$. At night the schools disperse, and the swimming speed drops to about $8 \mathrm{~cm} / \mathrm{s}$ (Katz 1978). 


\section{REFERENCES FOR SECTION 3}

Alabaster, J. S., and B. Scott. 1978. Swimming activity of perch, (Perca fluviatilis L.). J. Fish. Biol. 12:587-591.

Bainbridge, R. 1961. Problems of fish locomotion. Vertebrate Locomotion, Harris, J. E. (ed.). Symposia $7 \mathrm{nnt}$. Snr. London 5, 13=32.

Breder, C. M., Jr. 1976. Fish schools as operational structures. Fish Bu11., U.S. 74:471-502.

Brett, J. R. 1964. The respiratory metabolism and swimming performance of young sockeye salmon. J. Fish. Res. Board Can. 21:118.3-1226.

Bret.t., J. R. 196\%. Swimming performance uf suckeye salmon' (Uncorhynchus nerka) in relation to fatigue time and temperature. J. Fish. Res. Board Can. 24:1731-1741.

Brett, J. R. and N. R. Glass. 1973. Metabolic rates and critical swimming speed of sockeye salmon (Oncorhynchus nerka) in relation to slze and 'temperature. J. Fish. Res. Board Can. 30:379-387.

Broderius, S. J. 1970. Determination of Molecular Hydrocyanic Acid in Water and Studies of the Chemistry and Toxicity to Fish of the Nickelocyanide Complex. M.S. Thesis, Oregon State University, Corvallis. $93 \mathrm{pp}$.

Craig, J. F. 1977. Seasonal changes in the day and night activity of adult perch (Perca fluviatilis L.). J. Fish. Biol. 11:161-166.

Cranda11, C. A. and C. J. Goodnight. 1962. Effects of sublethal conrentratione of scveral toxicants un yruwlh of the common guppy (Lebistes reliculatus). Limnnol. Oreanngr. 7.233-239.

Davis, J. C. 1973. Sublethal efferts of bleached Kraft pulp mill effluont on recpiration and circulaliull in suckeye salmon (Uncorhynchus nirk.d). J. Fish. Res. Hoard Call. 30:369-377.

Davis, G. E., J. Foster, C. E. Warren, and P. Doudoroff. 1963. The influence of oxygen concentration on the swimming performance of juvenile Pacific salmon at various temperatures. Trans. Amer. Fish. Soc. $9: 111-124$.

Garton, R. R., and A. V. Nebeker. 1977. A multiple approach to solving the gas supersaturation problem. IN Tubb, P. (ed.), Recent Advances in Fish Toxicology, A Symposium, EPA Ecol. Res. Series 600/3-77-085. $203 \mathrm{pp}$. 
Howard, T.E. 1975. Swimming performance of juvenile coho salmon (Oncorhynchus kisutch) exposed to bleached Kraft pulp mill effluent. J. Fish. Res. Board Can. 32:789-793.

Katz, H. M. 1978. Circadian rhythms in juvenile American shad (Alosa sapidissima). J. Fish. Biol. 12:609-614.

Kelso, J.R.M. 1978. Diel rhythm in activity of walleye (Stizostedion vitreum vitreum). J. Fish. Biol. 12:593-599.

Leduc, G. 1966. Some Physiological and Biochemical Responses of Fish to Chronic Poisoning by Cyanide. Ph.D. Thesis, Oregon State University, Corvallis. $164 \mathrm{pp}$.

MacLeod, J. C. and L. L. Smith, Sr. 1966. Effect of pulpwood fiber on oxygen consumption and swimming endurance of the fathead minnow (Pimephales promelas). Fish. Soc. 95:71-84.

Nei1, J. H. 1957. Some effects of potassium cyanide of speckled trout (Salvelinus fontinalis). pp. 74-96. IN Papers Presented at the Fourth Ontario Industrial Waste Conference, Water and Pollution Advisory Committee, Ontario Water Resources Commission, Toronto, Canada.

Peterson, R. H. 1974. Influence of fenitrothion on swimming velocity of brook trout (Salvelinus fontinalis). J. Fish. Res. Board Can. 31: 1757-1762.

Ryder, R. A. 1977. Ambient light variations on behavior of yearling sub-adult and adult walleyes (Stizostedion vitreum vitreum). J.

Fish. Res. Board Can. 34:1482-1491.

Sevebrov, L. I. 1976. Relationship between school density and size of fish. J. Ichthyol. 16:135-140.

Smith, L. L., Jr., D. M. Oseid, I. R. Adelman, and S. J. Broderius. 1976. Effects of Hydrogen Sulfide on Fish and Invertebrates. Part I, Acute and Chronic Toxicity Studies. EPA Ecological Research Series, EPA600/3-76-062a. $286 \mathrm{pp}$.

Squire, J. L., Jr. 1978. Northern anchovy school shapes as related to problems in school size estimation. Fish. Bull., U.S. 76: 443-448.

Storch, T. W., D. W. Dufford, and K. T. Clement. 1978. The distribution of limnetic fish larvae in a flood control reservoir in central Illinois. Trans. Amer. Fish. Soc. 107:419-424.

Symon, P.E.K., and M. Heland. 1978. Stream habitats and behavioral interaction of underyearling and yearling Atlantic salmon. J. Fish. Res. Board Can. 35:175-183. 
Waiwood, K. G., and F.W.H. Beamish. 1978. Effects of copper, pH, and hardness on the critical swimming performance of rainbow trout (Salmo gairdneri Richardson). Water Res. 12:611-619.

Webb, P. W., and J. R. Brett. 1973. Effects of sublethal concentrations of sodium pentachlorophenate on growth rate, food conversion efficiency and swimming performance in underyearling sockeye salmon (Oncorhynchus nerka). J. Fish. Res. Board Can. 30:499-507.

Wu, T. Y., and G. T. Yates. 1978. A comparative mechanophysiological study of fish locomotion with implications for tuna-like swimming mode. IN Sharp and Dizon (eds.), The Physiological Ecology of Tunas. Academic Press, New York. 


\section{GENERAL TYPES OF FISH PASSAGE FACILITIES}

by

Milo C. Bell

Section 4 presents a brief description and schematic representation of the general types of facilities that are appropriate for upstream passage of fish around small scale hydroelectric dams. Design criteria relevant to each facility described here are given in Section. 5 .

Three types of facilities are available to move fish upstream around small scale hydroelectric dams: (1) fishways, (2) fish locks, and (3) fish lifts (also called fish elevators). In a fishway, fish swim up a series of pools, each of which is slightly elevated above the preceding pool. In a fish lock, fish are crowded into a lock chamber, raised above the dam by filling the chamber with water, and released over the dam. A fish lift works similarly to a fish lock, except that the former uses a water-filled mechanical hopper to raise fish above the dam.

\subsection{Pool and Weir Fishway}

The pool and weir fishway (Figure I) is probably the oldest of the designs. Its operation is deficient, mainly in the lack of capability to operate under fluctuating heads. A special regulating section is often incorporated at the upper or discharge end of the fishway system lo offset this disadvantage. This modification is made frequently, and designs are available. 


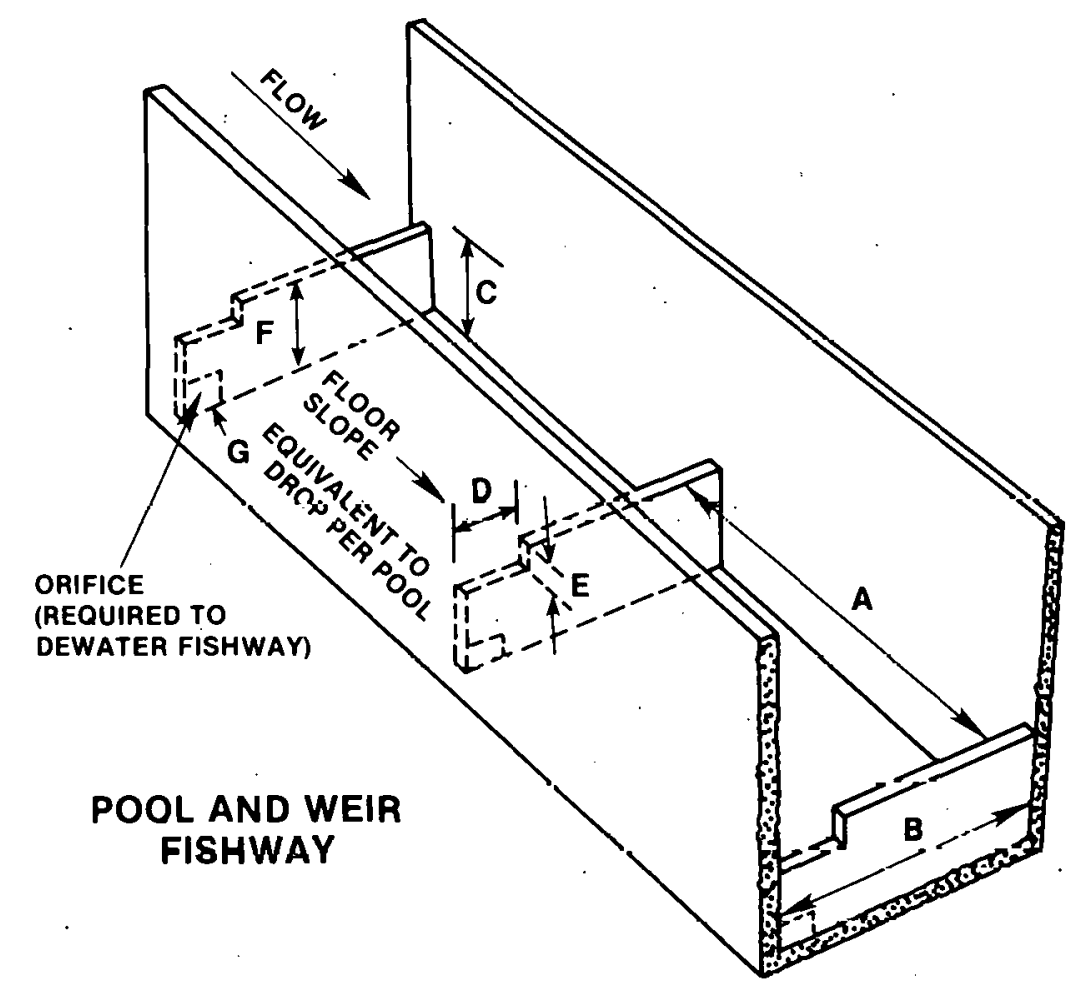

\begin{tabular}{|c|l|c|c|c|}
\hline A & POOL LENGTH & $6^{\prime}$ & $8^{\prime}$ & $10^{\prime}$ \\
\hline B & POOL WIDTH & $4^{\prime}$ & $6^{\prime}$ & $8^{\prime}$ \\
\hline C & WATER DEPTH & $3^{\prime}$ & $4^{\prime}$ & $6^{\prime}$ \\
\hline D & SLOT WIDTH & $0.5^{\prime}$ & $1.5^{\prime}$ & $1.5^{\prime}$ \\
\hline E & SLOT DEETH & $0.5^{\prime}$ & $0.5^{\prime}$ & $0.5^{\prime}$ \\
\hline F & DAFFLE HEIGHT & $2.5^{\prime}$ & $\mathbf{3 . 5 ^ { \prime }}$ & $5.5^{\prime}$ \\
\hline G & MINIMUM ORIFICE SIZE & $6^{\prime \prime} \times 6^{\prime \prime}$ & $8^{\prime \prime} \times 8^{\prime \prime}$ & $10^{\prime \prime} \times 10^{\prime \prime}$ \\
\hline & WATER DEPTH IN NOTCH & $12^{\prime \prime}$ & $12^{\prime \prime}$ & $15^{\prime \prime}$ \\
\hline DIGOIIAROC IN CF3 MIN & 1.05 & 4.0 & 4.0 \\
& NORMAL & 5.0 & 12.3 & 25.0 \\
& MAX & 24.0 & 36.0 & 48.0 \\
\hline DROP PER POOL & $9^{\prime \prime}-12^{\prime \prime}$ & $9^{\prime \prime}-12^{\prime \prime}$ & $9^{\prime \prime}=12^{\prime \prime}$ \\
\hline
\end{tabular}

Figure 1. Schematic representation of a pool and weir fishway. To convert feet (') to meters, multiply values shown by 0.3048 . To convert inches (") to centimeters, multiply values shown by 2.54. To convert cubic feet per second (CFS) to meters per second, multiply values shown by 0.02832 . 


\subsection{Vertical Slot Fishway}

The vertical slot fishway (Figure 2), which is commonly used on the Pacific Coast, is capable of operating with wide fluctuations of flow. The vertical slot design is more complicated than the pool and weir fishway, but it has the advantage of being self-regulating. The configurations shown on the legends have been either field- or modeltested. No regulating pool is required.

\subsection{Denil Fishway}

The Denil fishway (Figure 3 ), which is one of several variations of Denil's early design, has been used successfully. Its chief limitations are that (1) it is effective only with upstream pool variations of 0.9 to $1.2 \mathrm{~m}$ ( 3 to $.4 \mathrm{ft}$ ), and (2) it must be kept completely free from debris, which could alter the flow characteristics of the baffles.

Because the relationship of the baffle to the open area is critical, this system requires more maintenance than the other two fishway systems described.

\subsection{Fish Lock System}

Figure 4 shows an idealized lock system which uses an entrance bay with a $V$ trap entrance to hold the fish and a movable crowding device to move the fish into the lock chamber. This is a gravity or open lock, and although it can be automated, such automation can cause difficulties. A great advantage of the fish lock system is that it can move small fish or fish with weak swimming capabilities. 


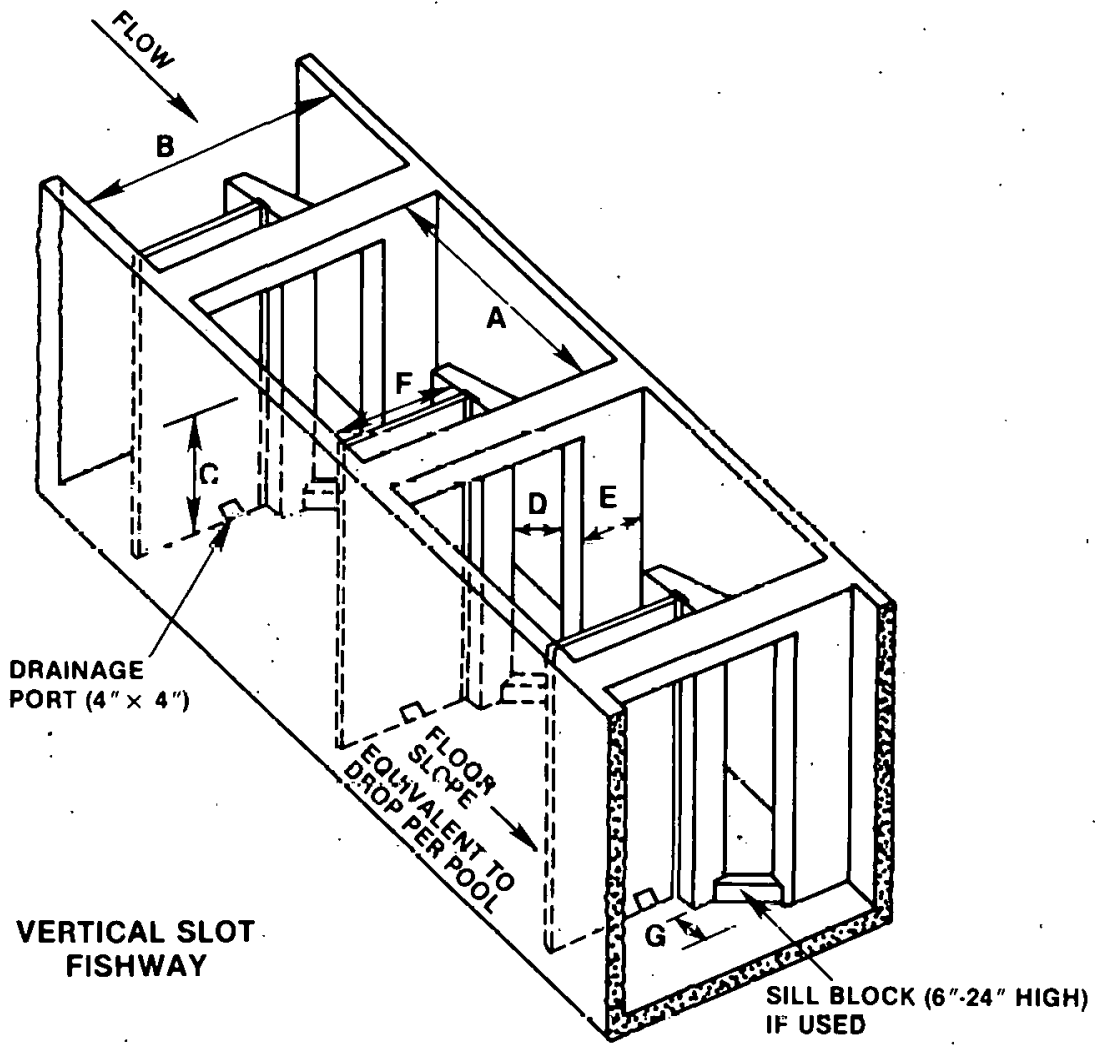

\begin{tabular}{|c|c|c|c|c|}
\hline A & POOL LENGTH & $6^{\prime}$ & $8^{\prime}$ & $10^{\prime}$ \\
\hline B & POOL WIDTH & 4 & $6^{\prime}$ & $8^{\prime}$ \\
\hline C & WATER DEPTH (MIN) & 21 & 3 & $\mathbf{3}^{\prime}$ \\
\hline$D$ & SLOT WIDTH & $0.5^{\prime *}$ & $0.76^{\prime *}$ & $1.0^{\prime *}$ \\
\hline $\mathbf{E}$ & WING BAFFLE LENGTH & $9^{\prime \prime}$ & $1 \cdot 3 \%_{8}^{\prime \prime}$ & $1^{\prime}-3^{3} \%_{8}^{\prime \prime}$ \\
\hline $\mathbf{F}$ & WING BAFFLE DISTANCE & 2 & $3 \cdot 1 " 1$ & $5^{\prime} \cdot 7^{\prime \prime}$ \\
\hline $\mathbf{G}$ & DISPLACEMENT OF BAFFLE & $4^{\prime \prime}$ & $5 \cdot 1 / 2 "$ & $5 \cdot 1 / 2 "$ \\
\hline $\begin{array}{l}\text { DIS } \\
\text { DEEP }\end{array}$ & $\begin{array}{l}\text { CHARGE PER FOOT OF } \\
\text { TH ABOVE BLOCK IN CFS }\end{array}$ & 3.2 & 4.8 & 6.4 \\
\hline & DRŌ Ṕ PER POOL & $9^{\prime \prime}-12 "$ & $9^{\prime \prime}-12 "$ & $9^{\prime \prime}-12^{\prime \prime}$ \\
\hline
\end{tabular}

Figure 2. Schematic representation of a vertical slot fishway. To convert feet (') to meters, multiply values shown by 0.3048 . To convert inches (") to centimeters, multiply values shown by 2.54. To convert cubic feet per second (CFS) to meters per second, multiply values shown by 0.02832 . 


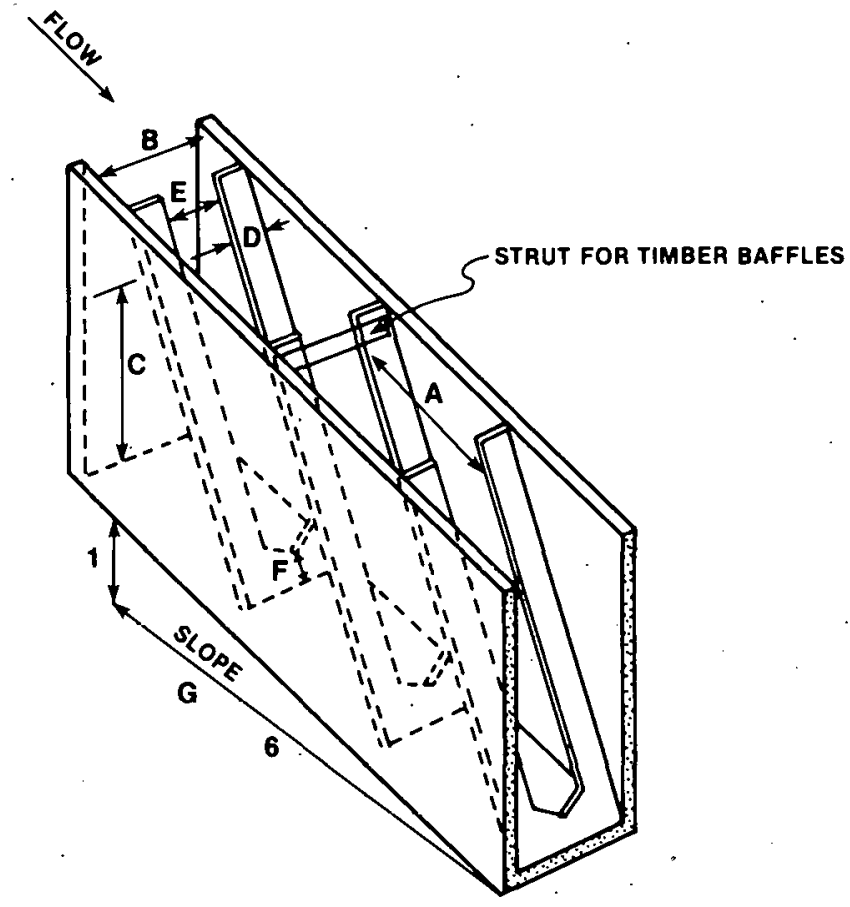

DENIL FISHWAY

\begin{tabular}{|r|l|c|c|}
\hline A & POOL LENGTH (BAFFLE SPACING) & $2^{\prime} \cdot 0^{\prime \prime}$ & $2^{\prime} \cdot 6^{\prime \prime}$ \\
\hline B & POOL WIDTH & $3^{\prime}$ & $4^{\prime}$ \\
\hline C & WATER DEPTH & $2^{\prime} \cdot 5^{\prime}$ & $2^{\prime} \cdot 5^{\prime}$ \\
\hline D & BAFFLE WIDTH & $7.5^{\prime \prime}$ & $10^{\prime \prime}$ \\
\hline E & SLOT WIDTH & $1.75^{\prime}$ & $2^{\prime} \cdot 4^{\prime \prime}$ \\
\hline F & BOTTOM BAFFLE NOTCH HT. & $9^{\prime \prime}$ & $12^{\prime \prime}$ \\
\hline G & FLOOR SLOPE & $1: 6$ & $1: 8$ \\
\hline DISCHARGE VARIABLE CFS.21 \\
\hline \multicolumn{3}{|c|}{ AV. VEL. 4 FP3 } \\
\hline
\end{tabular}

Figure 3. Schematic representation of a Denil fishway. To convert feet (') to meters, multiply values shown by 0.3048 . To convert inches (") to centimeters, multiply values shown by 2.54. To convert cubic feet per second (CFS) to cubic meters per second, multiply values shown by 0.02832 . To convert feet per second (FPS) to centimeters per second, multiply values shown by 30.48 . A resting pool $\left(15^{\prime}-20^{\prime}\right.$ long) should be provided for every $6^{\prime}$ to $7{ }^{\prime}$ of vertical lift. Baffles are usually constructed with $2^{\prime \prime} \times 10^{\prime \prime}$ or $2^{\prime \prime} \times 12^{\prime \prime}$ timber planks, marine plywood, or aluminum plate. 


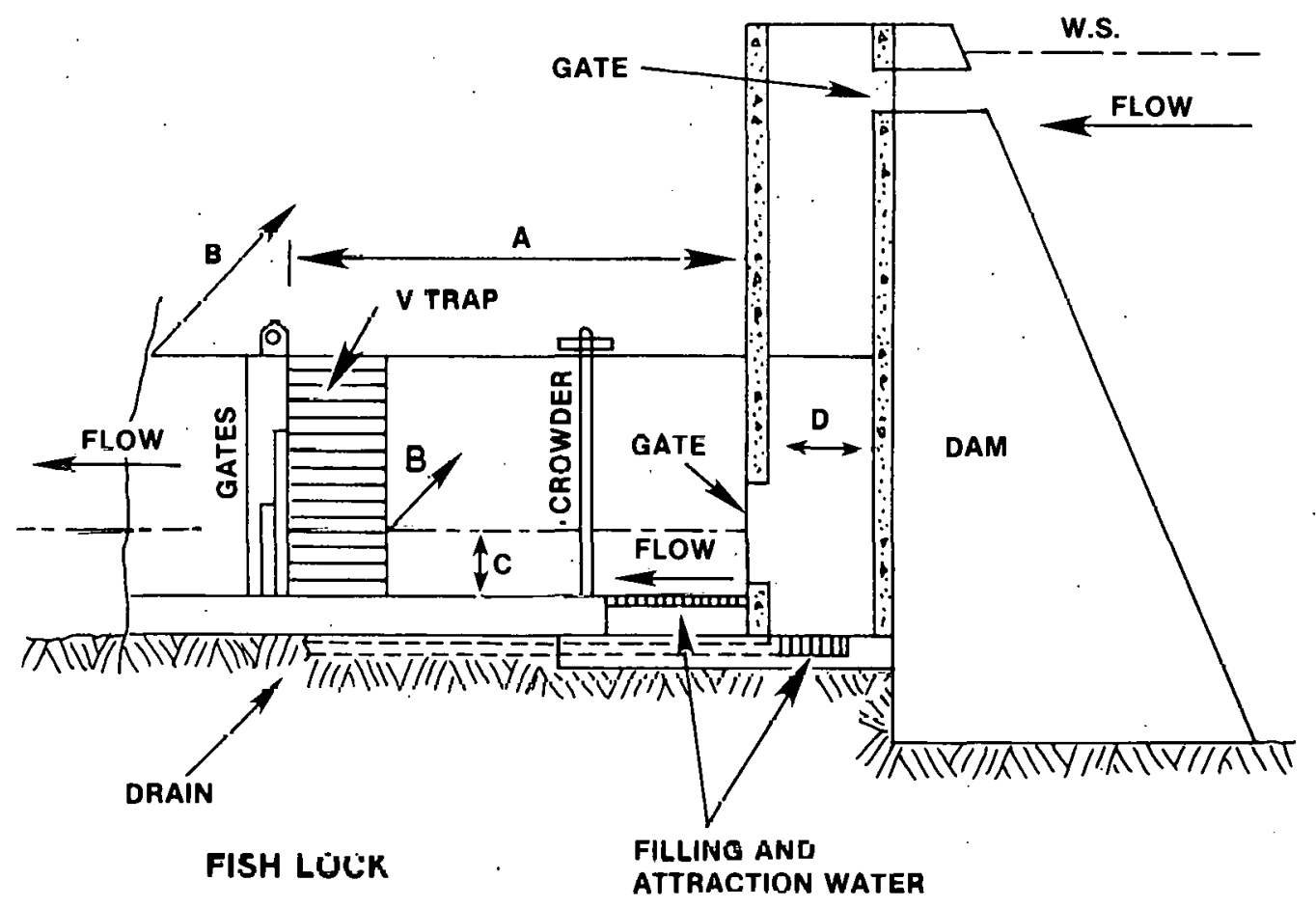

\begin{tabular}{|l|l|c|c|c|}
\hline A & POOL LENGTH & $8^{\prime}$ & $12^{\prime}$ & $16^{\prime}$ \\
\hline B & POOL WIDTH & $4^{\prime}$ & $6^{\prime}$ & $8^{\prime}$ \\
\hline C & WATER DEPTH (MIN) & $3^{\prime}$ & $3^{\prime}$ & $3^{\prime}$ \\
\hline D & LOCK CHAMBER & $24^{\prime \prime \prime}$ & $36^{\prime \prime 1}$ & $64^{\prime \prime \prime}$ \\
\hline & DISCHARGE VARIABLE (MIN) (CFS) & 30 & 30 & 30 \\
\hline
\end{tabular}

Figure 4. Schematic representation of a fish lock system. To convert. feet. (') to meters, multiply values shown by 0.3048 . To convert discharge (CFS) to cubic meters per second, multiply values shown by 0.02832 . 
The operation of an open fish lock is similar to that of a navigation lock. During the fishing period, a part of the attraction water would be discharged from the lock chamber. At the end of the fishing cycle, part or all of the fish in the holding area would be moved into the chamber, and the lower lock entrance would be closed. Filling would begin with transfer of the attraction water to the entrance bay so that variation in attraction outflow would be minor. As the lock finishes filling, the upper gate opens, and water is brought into the lock by opening the discharge gate. A brail may be needed. After the fish have left the lock, the upper gate is closed, the lock is drained to operating level, and the cycle is reestablished. Both fish locks and fish lifts (described below) require operating personnel ( 1 to 2 persons) to be present during operation.

\subsection{Fish Lift System}

A schematic of a fish lift or fish elevator system is shown in Figure 5. A fish lift requires a fish collection facility at tailrace level, with a fish entrance, $V$ trap, and fish crowding device, which forces fish into a water-filled hopper. Fish are lifted, as in an elevator, to the forebay level. At the upstream end, the fish can be passed into either a hauling tank or a water-filled trough for delivery into the pool area above the structure. Many devices of this type are in operation. The chief disadvantage of this system, as with the fish lork, is that. automated operation has not been successfully developed because of mechanical problems associated with unattended cycling at the entrance and delivery area. The chief advantage of the fish lift system is the flexibility in its cycling. Its operational cycles would be similar to those of a lock, without the need to fill and drain ports.

The biological advantage of fish locks and fish lifts is that they both ran pass practically all species of fish. Fish passage in a fishway is slower and species-selective. For example, striped bass, smelt, sturgeon, and blueback herring are reluctant to pass through fishways, especially those with lifts over $4.6 \mathrm{~m}$ (15 ft) (personal communication, Ben Rizzo, U.S. Fish and Wildlife Service, Newton Corner, MA 02158). 


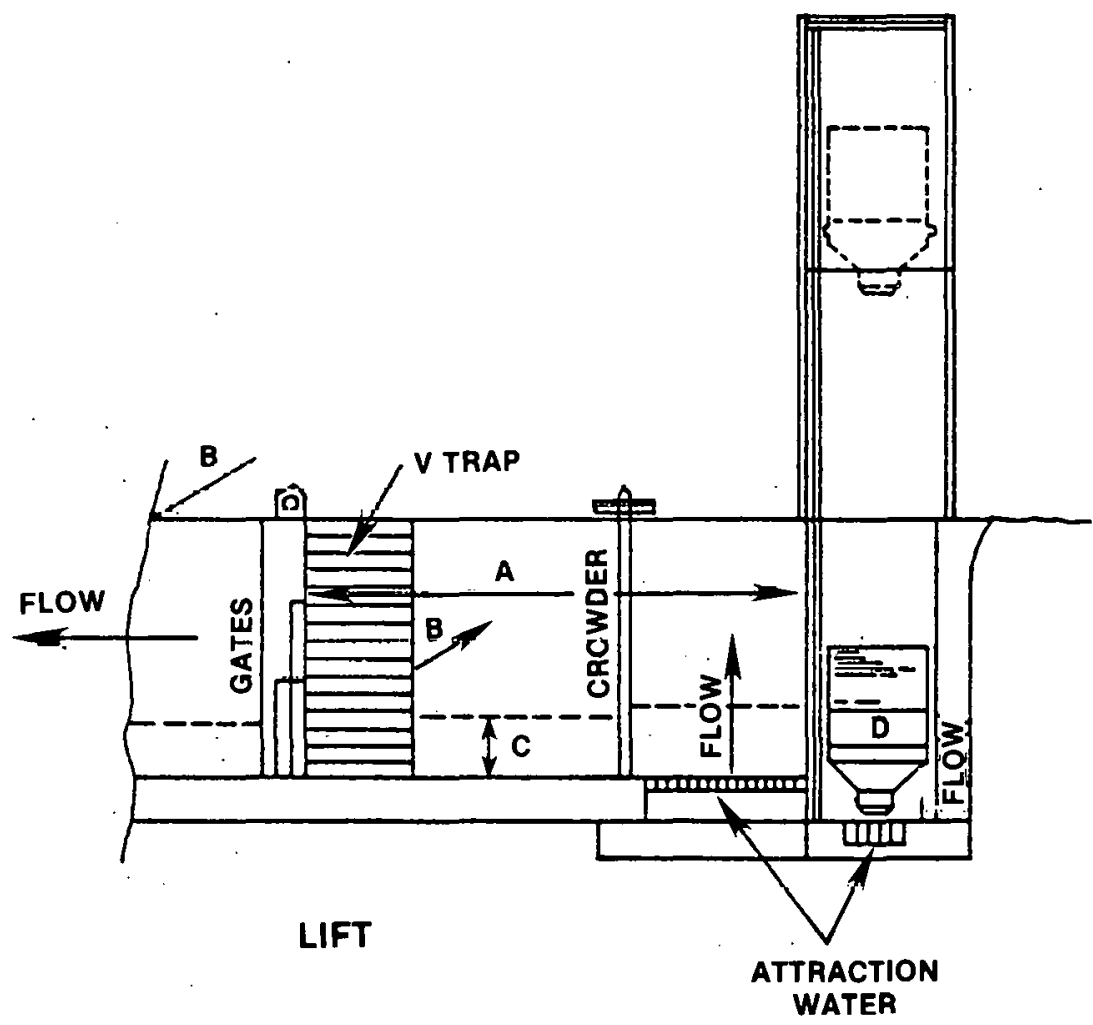

\begin{tabular}{|c|l|c|c|c|}
\hline A & POOL LENGTH & $8^{\prime}$ & $12^{\prime}$ & $16^{\prime}$ \\
\hline B & POOL WIDTH & $4^{\prime}$ & $6^{\prime}$ & $8^{\prime}$ \\
\hline C & WATER DEPTH (MIN) & $3^{\prime}$ & $3^{\prime}$ & $3^{\prime}$ \\
\hline D & HOPPER SIZE (GAL) & 250 & 500 & 750 \\
\hline DISCHARGE VARIABLE (MIN)(CFS) & 30 & 30 & 30 \\
\hline
\end{tabular}

Figure 5. Schematic representation of a fish lift system. To convert feet (') to meters, multiply values shown by 0.3048 . To convert gallons (GAL) to liters, multiply values shown by 3.785. To convert discharge (CFS) to cubic meters per second, multiply values shown by 0.02832 . 
5. GENERAL DESIGN CONSIDERATIONS FOR UPSTREAM

FISH PASSAGE FACILITIES

by

Milo C. Bell

Section 5 integrates the background material summarized in the previous sections to provide general considerations that may be important in the site-specific design of upstream fish passage facilities.

Before the preliminary design stage for upstream passage facilities is reached, several essential items should be resolved. The first is. the general attitude of the authorities toward the need of fish passage at specific sites. There may be physical or legal reasons for requiring passage or nonpassage. For example, barriers downstream may al ready limit the movement of fish, thus requiring a basinwide, rather than a site-specific approach to the problem. There may be biological problems. For example, the existence of a long-standing dam, the presence of which has completely altered the environmental conditions, may preclude the need for introducing additional species, and fish passage might not be recommended. Conversely, the wish to introduce more desirable or more sought-after species may make the necessary steps advisable.

Other matters that should be resolved before the preliminary design stage is reached are the collection of all physical and biological data on the project and a literature search for all pertinent biological requirements of the species involved.

Because the success of passage depends partly on good water quality, water quality parameters, which can alter the successful design criteria, should be ascertained. Water quality is discussed in more detail in Section 2 under the topics of oxygen requirements, supersaturation of nitrogen and pollutants that affect swimming performance, oxygen levels, and oxygen uptake by fish.

The swimming ability and behavior of fish species, under specified environmental conditions, forms the basis for many of the design criteria for upstream passage facilities. There are many possible variations as to the location and design of specific components of fish passage 
systems (exits, entrances, screens, bypass channels). Decisions regarding location of facility components must be made on a site-specific basis, and they must consider, where appropriate, the physical and biological issues discussed in this section.

In the final segment of Section 5, we present a checklist of pertinent design criteria that summarize the types of considerations discussed.

\subsection{Swimming Performance and Behavior}

Probably one of the most important aspects in fishway design is the ability of fish to swim through an opposing flow. Swinming ability dictates attraction velocities, water velocities in resting areas, and the distance of a run with a given velocity. As a first approximation, it may be assumed that a fish can swim at a velocity, in centimeters per second, equal to 12 times the length of the fish, in centimeters (or, in feet per second, equal to the length of the fish in inches). A maximum velocity of 600 to $700 \mathrm{~cm} / \mathrm{s}(20$ to $25 \mathrm{ft} / \mathrm{s})$ is assumed, regardless of length. A more conservative method by which to approximate velocity limils in a tishway that will ensure close to $100 \%$ passage would be to assume that the fish could swim a speed in contimeters per second equal to 6 times its body length in centimeters, but not. more than $244 \mathrm{~cm} / \mathrm{s}$ (ur, In feet per second of less than half its body length in inches, but not more than $8 \mathrm{ft} / \mathrm{s}$ ). Design velocities affect. nnt. only the ability of fish to negotiate the system, but also the size (and thus the cost) of the fishway The following examiste will 111ustrate this point.

The velocity of falling water can be estimated from the relation

$$
V=\sqrt{2 g h}
$$

where

$$
\begin{aligned}
& V=\text { velocity, cm/s }(\mathrm{ft} / \mathrm{s}) \\
& g=\text { acceleration due to gravity equal to } 975 \mathrm{~cm} / \mathrm{s} \cdot(32 \mathrm{ft} / \mathrm{s}), \\
& h=\text { head of drop, } \mathrm{cm}(\mathrm{ft}) .
\end{aligned}
$$


If fish are to be passed over $30.5 \mathrm{~cm}(1 \mathrm{ft})$ of head, the fish would have to be capable of swimming (through solution of the above equation) at least $243.8 \mathrm{~cm} / \mathrm{s}(8 \mathrm{ft} / \mathrm{s})$. If, however, the species to be passed can only swim $121.9 \mathrm{~cm} / \mathrm{s}$ ( $4 \mathrm{ft} / \mathrm{s}$ ), solution of the above equation for

$$
h=\frac{V^{2}}{2 g}
$$

yields $h=7.6 \mathrm{~cm}(0.25 \mathrm{ft})$. This means that the fish swimming at 121.9 $\mathrm{cm} / \mathrm{s}(4 \mathrm{ft} / \mathrm{s})$ could only negotiate a $1 \mathrm{ift}$ of $7.6 \mathrm{~cm}(0.25 \mathrm{ft})$. Under the same assumption of $30.5 \mathrm{~cm}(1 \mathrm{ft})$ of head at a site, four $7.6-\mathrm{cm}$ $(0.25-\mathrm{ft})$ drop pools in a fishway would be necessary to allow this fish to pass successfully. In a similar fashion, if the fish could only swim $60.9 \mathrm{~cm} / \mathrm{s}$ ( $2 \mathrm{ft} / \mathrm{s}), 16$ pools in the fishway would be required for each $30.5 \mathrm{~cm}(1 \mathrm{ft})$ of head drop.

As the cost of a fishway is, in part, a function of the number of pools required (Section 6), the importance of swimming ability to overall project economics is obvious. For fish species with limited swimming ability or special behavioral characteristics, fishway systems could be eliminated from consideration in favor of a fish lock or a fish lift, where swimming ability is not related to successful passage as discussed here. In the fish lock and fish lift, once fish are in the chamber, they are moved over the head, either by a mechanical hopper or by the lock system. Thus, the swimming ability of the smallest fish to be passed in a conventional fishway must be known, because the smallest fish will determine the allowable velocities in a fishway system. It may be desirable to conduct swimming tests on the species of fish to be passed at a given site if adequate information is not available in the literature.

Other limiting factors that must be considered with respect to fish swimming ability are the water temperature, dissolved oxygen. level, and the level of pollution at a site. If low oxygen or pollutants were present, then an upper limit of $243.8 \mathrm{~cm} / \mathrm{s}(8 \mathrm{ft} / \mathrm{s})$ would have to be scaled down to accommodate modified swimming performance (see Section 3). If a system through which fish may swim freely by either a trap 
or a lock must be replaced, then provision must be made for an entrance holding pool and a means of artificially moving the fish from that pool: Therefore, an understanding of the minimum length of $f i s h$ to be passed and the biological conditions present in the river system is essential to ensure that the design chosen will operate successfully.

Fish are cold-blooded animals that react to the temperature of their immediate environment. Increases or decreases in temperature may reduce the urge of fish to migrate upstream. Each species has an optimal temperature range, and temperatures ahove or below that range affect the swimming efficiency of that species. Seasonal variations in water temperature above or helow the optimum range; may require flexi. bility in the design velocity to accommodate the lessened ability of the fish to swim.

If a particular fishway is designed with velocities that would require fish to swim near their maximum velocity for extended periods, resting areas will be required within the system. Fishway designs that require maximum swimming performance should be avoided where feasible. Resting areas would allow fish to regain their oxygen balance and eliminate excess lactic acid accumulated during extended swimming periods. The maximum water velocity allowable in fish resting areas varies with fish length, but a first approximation of resting area velnoities would be $10 \%$ of the normal swimming capability.

Swimming performance should not be the only criterion used in designing fishways. The general behavioral patterns of the fish must also be understinnd. If fish do not have sufficienl Ilullvation to overcome difficulties of upstream passage, they will not move through any facility. Motivation may require them to (1) accept. flows that are slower than the normal flow of a stream, (2) accept cunstraint in manmade pools or traps, (3) enler restricted openings, and (4) accept light and shadow patterns and, perhaps, less-than-normal swimming depths: In some instances, barriers may be caused by temperature gradients and adverse olfactory reactions. If the fish are not discouraged by space or other constraints, certain workable criteria for various species may be applied. 
The motivation of the fish (strong or weak) to move upstream or downstream must be known. Fish may move upstream for purposes of spawning or rearing, obtaining food, and avoiding unpleasant temperatures (see Section 2). They may move downstream to seek feeding and rearing areas, reduce their density, avoid predation, or find more suitable temperatures.

The behavior of various species of fish indicates that individuals require separation from other fish in schools (see Section 3). A violation of these requirements can result in excessive activity, in the fish dropping back through a fishway system, or in the fish being damaged while attempting to find exits. A general rule can be applied.that, for each kilogram (pound) of fish, $0.013 \mathrm{~m}^{3}\left(0.2 \mathrm{ft}^{3}\right)$ of space should be supplied. This rule must be used with caution, however, because some species do not practice layering and, thus, would not fully utilize the depth of the pool. As an example, perhaps $80 \%$ of some fish species may be contained in the top 0.9 to $1.8 \mathrm{~m}$ ( 3 to $6 \mathrm{ft}$ ) of a fishway pool or chamber (see Section 4).

When fish are passed by being crowded into a lift hopper filled with water, they become extremely agitated and have a high oxygen consumption rate. With a base loading of $2: 25 \mathrm{~kg}$ of fish per $0.03 \mathrm{~m}^{3}$ (5 $\mathrm{lb} / \mathrm{ft}^{3}$ ) and with water that is $10^{\circ} \mathrm{C}$ and saturated with oxygen, fish will survive for $16 \mathrm{~min}$, by which time the oxygen level will have dropped to $4 \mathrm{ppm}$. If the crowding level were to be doubled, the loading and hoisting time could not exceed $8 \mathrm{~min}$.

In the operation of a lock, once the fish enter the lock chamber, the filling water will provide extra oxygen and extra space needed. Fish tests with locks have shown that, because fish may be reluctant to leave the lock, a brail-type lift is often needed to ensure quick exit of the fish. 
5.2. Attraction Flows, Entrance-Exit Considerations, and Typical Location of Passage Systems

Fish entering a fishway system are usually required to leave a stream that is larger than the fishway entrance system, which is generally supplied with only a fraction of the total stream flow.

Regardless of the type of passage system used, attraction water must be available to encourage the fish to leave the normal river flow and enter the device. Discharge through fishways usually requires flow duymentation by gravity or pumping to supply attraction water.

The moat effective location for entrances to mist.redill rish fac111ties are along shorelines. Entrances to fish passage facilities are usually located at the point of farthest upstream travel of a fish adjacent to spillways or turbine discharges. Consequently, flows from such facilities must compete with discharqes from power whepls or spillways and sluices. If the entrance to a fish passage facility is located at the shoreline, the attraction outflow should approximate $3 \%$ of the adjacent discharge from either a spillway bay or turbine. At small projects, $3 \%$ of the average annual stream flow during the time of risli passage should provide adequate attraction flows. If the fishway could not supply this quantity, the water would have to be supplied, as in the case of a lock or lift, into the entrance area. This water is usually supplied by providing diffusion areas in which the velocity would not be over $30.5 \mathrm{~cm} / \mathrm{s}$ ( $1 \mathrm{ft} / \mathrm{s}$ ) over the gross area of the outlet cover.

Attraction problems can frequently be minimized by manipulating the power wheels and the spillway to obtain the best conditions at the fishway entrance or to lead the fish to the fishway entrance.

Fish appear reluctant to enter a fishiway system, and they tend to accuinulate more in the first few pools than in the upper pools. Until the fish become accustomed to the constraints, any change in flow pattern, as that occurring at a turn, usually results in accumulation at that point. Turn pools provide resting areas for fish in fishways.

Lucks and lifts, unless used with a crowder, appear to be more successful when used with a short fishway system that allows the fish 
to become accustomed to the new environment. The fish seem to enter a lock more readily with this provision. This is obviated by the use of a crowder, which is usually necessary.

Some species refuse to surface or jump and must be accommodated by underwater ports. Conversely, certain species prefer surface passage. Jumping ability is a design criteria primarily restricted to salmonid species. Design criteria for nonsalmonids usually are intended to discourage "jumping" because of possible injury to fish.

If the behavior of the species involved is not known, experiments should be conducted to determine the pattern of movement to prevent failure because of improper location of the internal passageways of the system. The possible reluctance of species to enter either brightened or darkened entrance areas should be determined. Best results are sometimes obtained by backlighting entrances to darkened areas.

At low head dams the fish are not likely to experience vertical temperature gradients within a pool severe enough to inhibit their movement. However, ensuring that the temperature of the fishway discharge water approximates that of the receiving water of the river at the point where the fish enter a system would be prudent.

The exit position of any fish passage device is important. If it is located near an open spillway, the potential for fish falling back can be increased. If the fish are passed through a lock or hoist, specifically the latter, the oxygen imbalance that results from their agitation must be corrected. Fallback, which is a normal behavior tendency of many anadromous fish in fishways, may result from disorientation or from the need for additional resting time. The exit, therefore., should be located in a quiet area, where the fish can readily find a low-velocity flow to lead them upstream. They should not be permitted to enter a high-velocity flow at right angles to the current.

Fish species may differ in their response to submerged versus surface orifices in a fishway. As an example, although. salmon use (and generally prefer.) submerged orifices, shad do not readily accept such passageways; thus, fishway systems in which both species are present require both surface and submerged passageways. 
The normal yearly passage times for migrating fish species are generally well defined. The time of passage within a 24-h period is not so well defined, but it is generally assumed that fish do not move actively.during darkness. If only one species were to be passed, the operation of fish facilities would be required only during the normal yearly passage times of that species. However, with the overlapping of several species with different passage times, the day passage period may be the most important factor in water conservation studies.

To help in understanding the problem of locating fishways, Figure 6 shows possible locations near a dam with a power canal that takes advantage of the stream drop to locate the power plant some distance downstream from the dam. The figure also shows facility layout at a dam that has a powerhouse associated with the dam structure.

Fish will come to both the discharges from the power wheels and the spillway, unless a spillway can be created at a powerhouse to eliminate spill over the dam during upstream migration periods. In the case of the power canal configuration, a minimum of two fishways would be required unless the spill is adjacent to the powerhouse. In the case of the associated powerhouse and dam, one fishway might suffice with a concentrated spill near the powerhouse. Only with the specific information on the river discharges related to water use patterns, can such a decision on numbers be made.

A fish facility entrance must be located in an area that attracts the fish to the entrance. Such locations are generally downstream from the crest of a hydraulic jump or unatream from the boil from the turbilie. Maximum and minimum levels for fishway operation should be set, taking into account at least the normal flood level.

Entrance attraction velocities should he commensurate with the fish's ability to swim and should not ixceed lhe sustalned speed (see Section 3), but may equal as much as twice the cruising speed. Average transportation velocities in channels leading to passageways can equal about one-half of the cruising speed (see Sertion 3). Typical entrance velocities range from 121.9 to $243.8 \mathrm{~cm} / \mathrm{s}$ ( 4 to $8 \mathrm{ft} / \mathrm{s}$ ). 

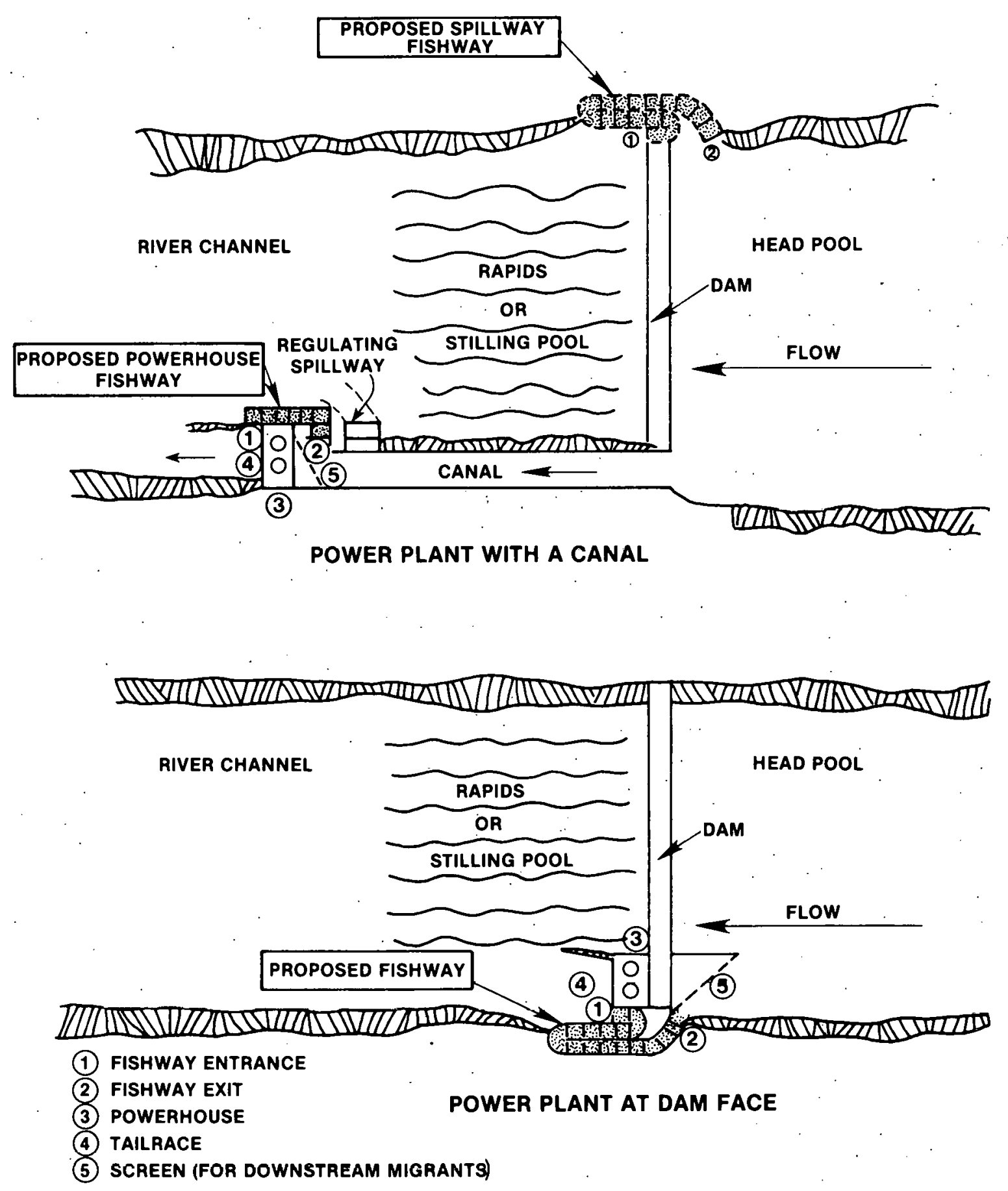

Figure 6. Schematic representation of typical location of fish passage facilities. 
To maintain a suitable fishway pattern, it is recommended that the energy absorbed per pool does not exceed $4 \mathrm{ft}-1 \mathrm{~b}$ per cubic foot of water. A weir overflow need not be full-width, and an orifice size may be tailored in cross section to permit passage of the maximum-sized fish expected.

For purposes of design, fish may be assumed to require 2.5 to 4 min to pass $30.5 \mathrm{~cm}$ ( $1 \mathrm{ft}$ ) of vertical height in a fishway system.

Generally, if a spillway discharge occurs during all or a major part of the upstream inigration period, if a dam is of considerable length, and if a powerhouse discharge occurs at the base of the dam, two fishways (one on either bank) should be provided. Figure 6 illustrates a condition in which most of the flow would pass through the powerhouse so that the fish would be attracted to a single fishway in the tailrace area. Projects commonly include a canal leading to a powerhouse some distance downstream from the spillway dam. If there is a continuous spill, then fishways may be needed at both the powerhouse and the spillway dam.

One variation would be to minimize the powerhouse discharge during fish migration time and supply one or more fishways at the spiliway dam. Another variation would be to provide a regulated spillway at the powerhouse and also a fishway that would take advantage of the discharge frum lie turbines and trom the regulated spillway. All these designs have been used. Site-specific information is necessary to make a proper decision as to the loçations and numbers of fishways needed.

\subsection{Checklist of Pertinent. Design Data}

The reasons for certain elements in the design of upstream passage facilities have heen discussed in Scctions 5.1 and 5.2. We present here in summary form (Table 4) a checklist of general design criteria that can be used for very early design analysis. We emphasize that this checklist should not replace a detailed site-specific analysis. The U.S. Fish and Wildlife Service, in cooperation with state and fishery agencies, can provide site-specific design and operational criteria if a project layout is available. 
Table 4. Checklist of pertinent design data for upstream passage facilities

\begin{tabular}{|c|c|}
\hline Design feature & Approximate design data \\
\hline Pool sizes and shapes in fishways & See Figures $1,2,3$ \\
\hline $\begin{array}{l}\text { Maximum flows in fishways. } \\
\text { (energy must be dissipated in } \\
\text { each pool) }\end{array}$ & $\begin{array}{l}\text { Based on energy dissipation of } \\
4 \mathrm{ft}-\mathrm{lb} / \mathrm{s} \text { per cubic foot of } \\
\text { water in pool, or a maximum } \\
\text { velocity of } 4 \mathrm{ft} / \mathrm{s} \text { in Denil } \\
\text { type. }\end{array}$ \\
\hline Resting areas & $\begin{array}{l}\text { Assumed to be velocities of } 30.5 \\
\mathrm{~cm} / \mathrm{s}(1 \mathrm{ft} / \mathrm{s}) \text { or less in pools, } \\
\text { or } 0.1 \% \text { of normal swimming } \\
\text { speeds. Denil requires } \\
\text { special resting pools. }\end{array}$ \\
\hline Orifices--number and size & $\begin{array}{l}\text { None shown. If used, they. } \\
\text { should be a size to allow } \\
\text { passage of maximum-sized. } \\
\text { fish. }\end{array}$ \\
\hline Drop between poois & $\begin{array}{l}30.5 \mathrm{~cm}(1 \mathrm{ft}) \text { as shown, but } \\
\text { should be tailored to require- } \\
\text { ments of species to be } \\
\text { passed, or sloped for Denil } \\
\text { type. }\end{array}$ \\
\hline $\begin{array}{l}\text { Average maximum velocities } \\
\text { over weirs or through orifices }\end{array}$ & $\begin{array}{l}243.8 \mathrm{~cm} / \mathrm{s}(8 \mathrm{ft} / \mathrm{s}) \text { maximum or } \\
\text { based on drop per pool. } \\
\text { Maximum of } 121.9 \mathrm{~cm} / \mathrm{s} \\
(4 \mathrm{ft} / \mathrm{s}) \text { in Denil. }\end{array}$ \\
\hline Entrance velocities & 1.9 to $3.8 \mathrm{~cm} / \mathrm{s}(4$ to $8 \mathrm{ft} / \mathrm{s})$ \\
\hline $\begin{array}{l}\text { Water depth as a weir measurement } \\
\text { over a pool weir }\end{array}$ & $\begin{array}{l}15.2 \mathrm{~cm}(0.5 \mathrm{ft}) \text { minimum; } 30.5 \\
\cdot \mathrm{cm}(1 \mathrm{ft}) \cdot \mathrm{maximum} .\end{array}$ \\
\hline $\begin{array}{l}\text { Transportation or directional } \\
\text { flow velocities in flat or } \\
\text { drowned-out areas of fishways }\end{array}$ & 30.5 to $60.9 \mathrm{~cm} / \mathrm{s}(1$ to $2 \mathrm{ft} / \mathrm{s})$ \\
\hline Exit locations & $\begin{array}{l}\text { Generally in low velocities of } \\
30 \mathrm{~cm} / \mathrm{s}(1 \mathrm{ft} / \mathrm{s}) \text { or less. } \\
\text { Positive toward downstream. }\end{array}$ \\
\hline Travel time through fishway & $\begin{array}{l}\text { Assume } 2.5 \text { to } 4 \text { min per } \\
\text { pool, or } 15 \mathrm{~s} \text { in a Denil } \\
\text { swim sectlon. Denil should } \\
\text { provide equivalent time in } \\
\text { resting pool. }\end{array}$ \\
\hline
\end{tabular}


Table 4 (continued)

\begin{tabular}{|c|c|}
\hline Design feature & Approximate design data \\
\hline Space for fish in pool. & $0.013 \mathrm{~m}^{3} / \mathrm{kg}\left(0.2 \mathrm{ft}^{3} / \mathrm{lb}\right)$ of fish. \\
\hline $\begin{array}{l}\text { Space in trapping or holding } \\
\text { pool }\end{array}$ & $0.013 \mathrm{~m}^{3} / \mathrm{kg} .\left(0.2 \mathrm{ft}^{3} / \mathrm{lb}\right)$ of $\mathrm{fish}$ \\
\hline Space in lift tanks & $\begin{array}{l}\text { Based on pounds of fish per } \\
\text { minute of transfer time, or } \\
\text { added oxygen in system. }\end{array}$ \\
\hline Space in fish locks & $\begin{array}{l}0.013 \mathrm{~m}^{3} / \mathrm{kg}\left(0.2 \mathrm{ft}^{3} / \mathrm{lb}\right) \text { of fish } \\
\text { If crowded at release, based } \\
\text { on kilograms of fieh hold pcr } \\
\text { minute of transfer time. }\end{array}$ \\
\hline Estimated passage period's & $\begin{array}{l}\text { Assume } 60 \% \text { from daylight to } \\
1 \text { PM; } 40 \% \text { from } 1 \text { PM to dark- } \\
\text { ness; night passage may equal } \\
3 \text { to } 5 \% \text { of day's total. Rc- } \\
\text { quires project verification. }\end{array}$ \\
\hline Entrance eddies & $\begin{array}{l}\text { Recommended that cross } \\
\text { velocity not exceed } 60.9 \\
\text { r.m } / \mathrm{s}(2 \mathrm{ft} / \mathrm{s}) \text { at zero fishway } \\
\text { discharge. Loes if small fish } \\
\text { are to be passed. Eliminate } \\
\text { if possible. }\end{array}$ \\
\hline $\begin{array}{l}\text { Auxiliary water introduction } \\
\text { into fishway for entrance } \\
\text { attraction or transportation } \\
\text { velocities }\end{array}$ & $\begin{array}{l}\text { Vertical velocity over bottom } \\
\text { diffusion areas }-7 \text { tn } 30.5 \\
\mathrm{~cm} / \mathrm{s}(0.25 \text { to } 1.0 \mathrm{ft} / \mathrm{s}) \text {. } \\
\text { Horizontal velocities over side } \\
\text { dlrrusor }--7 \text { to } 30.5 \mathrm{~cm} / \mathrm{s} \\
(0.25 \text { to } 1.0 \mathrm{ft} / \mathrm{s}) .\end{array}$ \\
\hline $\begin{array}{l}\text { Control section to match forebay } \\
\text { regulations for pool-type } \\
\text { fishway }\end{array}$ & $\begin{array}{l}\text { Not described subject to } \\
\text { specific site requirements. } \\
\text { Designs available. }\end{array}$ \\
\hline Collection system & See Figures 4 and 5 . \\
\hline Fish locks. & $\begin{array}{l}\text { See Figure } 4 \text { and description } \\
\text { in text. }\end{array}$ \\
\hline Fish lifts & $\begin{array}{l}\text { See Figure } 5 \text { and description } \\
\text { in text. }\end{array}$ \\
\hline
\end{tabular}


Table 4 (continued)

\begin{tabular}{lc}
\hline Design feature & Approximate design data \\
\hline Source of auxiliary water supply & $\begin{array}{l}\text { Gravity (with energy dis- } \\
\text { sipators), pumps or special } \\
\text { turbines. }\end{array}$ \\
Fish counting and/or trapping facilities & $\begin{array}{l}\text { May be required; normally } \\
\text { placed at upstream end of } \\
\text { fish passage facility. }\end{array}$ \\
\hline
\end{tabular}




\section{REFERENCES FOR SECTION 5}

Beil1, M. C. 1949. Experimental work on fishways-model and proto-type. Unpublished. International Pacific Salmon Fisheries Commission, New Westminister, British Columbia.

Be11, M. C. 1973. Fisheries Handbook of Engineering Requirements and Biological Criteria. Report for U.S. Army Corps of Engineers, North Pacific Division, Fisheries-Engineering Research Program, Contract No. DACW57-68-C-0086, Portland, Oregon.

Be 11, M. C., and A. C. DeLacy. 1972. A Compendium on the Survival nf Fish Passing Ihrough Spilliways and Condulits. Report for the U.S. Army Curps nf Fngineers, North Pacific Distriet, Cuilhrdul Nu. DACW57-67-C-0105, Portland, Oregon.

Be11, M. C., A. C. Delacy, and G. J. Paulik. 1967. A Compendium on the Success of Passage of Small Fish Through Turbines. Report for the U.S. Army Corps of Engineers, North Pacific District, Contract No. DA-35-026-Civeng-66-16, Portland, Oregon.

Black, E. C. 1958. Energy stores and metabolism in relation to muscular activity in fishes. pp. 51-67. IN P. A. Larkin (ed.), The Investigation of Fish-Power Problems, Symposium held at the University of British Columbia, April 29-30, 1957. University of British Columbia, Institute of Fisheries, Vancouver.

Brett, J. R., M. Hollands, and D. F. Alderdice. 1958. The effect of temperature on the cruising speed of young sockeye and coho. silim.n. J. Fish. Res. Board Can. 15(4):587=605.

Carney, R. E., and R. J. Adkins. 1955. Reactions of young silver salmon in ten velocity combinations. Unpublished report. School of Fisheries, Technical Report No. 23:1-15. University of Washington, Seatt.le.

Clay, C. H. 1955. A procedure for installation of fishways at natural ubstructions. Cian. Fish Cult. 17:1-12.

Clay, C. H. 19G1. Desiyn of flsliways and other fish facilities. Canada Department. of Fisheries, Olluwa, Canada.

Collins, G. B. 1951. A fishway that shad ascend. U.S. Fish and Wildlife Service, Special Scientific Report--Fisheries, No. 65. Washington, D.C.

Collins, G. B., C. H. Elling, J. R. Gauley, and C. S. Thompson. 1963. Effect of fishway slope on performance and biochemistry of salmonids. Fish. Bul1. 63(1):221-253. 
Craddock, D. R. 1951. "Review of literature on guiding fish with lights, fish vision, and reactions of fish to light." Submitted to the U.S. Army Corps of Engineers. Work Item A-9, unpublished, U.S. Fish and Wildlife Service, Pacific Salmon Investigations, Seattle, Washington.

Elling, C. H. 1960. Further experiments in fishway capacity, 1957. U.S. Fish and Wildlife Service, Special Scientific Report--Fisheries, No. 340. Washington, D.C.

Fields, P. E. 1966. Migrant salmon light guiding studies at Columbia River dams. Final report submitted to the U.S. Army Corps of Engineers, North Pacific, Fisheries Engineering Research Program, Contract No. DA-45-108-Civeng-63-29.

Fields, P. E., G. L. Finger, and L. A. Verhoeven. 1954. The use of a chain barrier to guide young salmon. School of Fisheries, Report No. 1:1-11. University of Washington, Seattle.

Fisk, L. 0. 1959. Experiments with a vertical baffle fishway. Calif. Fish Game 45(2): 111-122.

Fulton, L. A., H. A. Gangmark, and S. H. Bair. 1953. Trail of Denil-type fish ladder on. Pacific salmon. U.S. Fish and Wildlife Service, Special Scientific Report--Fisheries, No. 99. Washington, D.C.

Furuskog, V. 1945. A new fishladder. Swed. Fish. Mag. 11:236-239.

Harry, A. 1917. The fishways in the dams and waterworks in Switzerland. Swiss Wasserwirtschafts-Verbandes No. 5. Verlag Rascher $V$ Co., Zurich and Leipzig.

Holmes, H. B. 1948. History, development, and problems of electric fish screen. U.S. Fish and Wildlife Service, Special Scientific Report--Fisheries, No. 53. Washington, D.C.

Idler, D. R., and W. A. Clemens. 1959. The energy expenditures of Fraser River sockeye salmon during the spawning migration to Chilko and Stuart Lakes. International. Pacific Salmon Fisheries Commission, Progress Report No. 6. New Westminster, British Columbia.

Institution of Civil Engineers, Institution Research Committee. 1942. Report of the Committee on Fish-Passes. London.

International Pacific Salmon Fisheries Commission. 1948. Hydraulic Characteristics of the 20-ft-Wide Twin-Jet Vertical Slot Fishway. New Westminster, B.C.

Kerr, J. E. 1953. Studies of Fish Preservation at the Contra Costa Steam Plant of the Pacific Gas and Electric Company. California Department of Fish and Game, Fish Bull. 92. 
Kipper, Z. M., and I. V. Mileiko. 1962. Fishways in Hydro Developments of the USSR. Rybnoe Khozyaistvo, Moscow.

Translated by $A$. Wald, Israel Program for Scientific

Translations, Ltd. U.S. Department of Commerce, Clearinghouse

for Federal Scientific and Technical Information, Springfield,

Virginia. 1967.

Lander, R. H. 1959. The Problem of Fishway Capacity. U.S. Fish and Wildlife Service, Special Scientific Report--Fisheries, No. 301. Washington, D.C.

Long, C. W. 1959. Passage of Salmonoids Through a Darkened Fishway. U.S. Fish and Wildlife Service, Special Scientific Report -Fisheries, No. 300. Washington, D.C.

McKinley, W. R., and R. D. Webb. 1956. A Proposed Correction of Migratory Fish Problems at Box Culverts. Washington Department of Fisheries, Fisheries Research Papers, 1.(4):33-45.

McLeod, A. M. , and P. Nemenyi. 1939-40. An Investigation of Fishways. University of Iowa Studies in Engineering, Bul1. 24. Conducted for the Iowa State Conservation Commission by the Iowa Institute of Hydraulic Research, Iowa City.

Paulik, G. J., and A. C. DeLacy. 1957. Swimming Abilities of Upstream Migrant Silver Salmon, Sockeye Salmon and Steelhead at Several Water Velocities. School of Fisheries, Technical Report 44, University of Washington, Seattle.

Sakowicz, S., and S. Zarnecki. 1954. Pool-type fishways--biological aspects in their construction. Roczniki Nauk Rolniczych 69 (Series 0):5-1.1\%. Translated from Polish, U.S. Department of Commerce, Office of Technical Services, Washington, D.C. 1962.

Wayne, W. W. 1960. Fish handling facilities for Baker River hydro-electric project. Presented at Annual Convention of American Society of Civil Engineers. Unpublished.

Weaver, C. R. 1965. Observations on the swimming ability of adult American shad (Alosa sapidissima). Trans. Amer. Fish. Soc. $94(4) ; 382-.385$.

Ziemer, P. E. 1962. Steeppass Fishway Development. Alaska Department of Fish and Game, Informational Leaflet No. 12. 


\section{BASIC COST CONSIDERATIONS}

by

Milo C. Bell and Eugene P.. Richey

The cost of constructing and operating similar upstream fish facilities for small scale hydroelectric plants will vary from project to project. A complete cost estimate should include all the development, engineering, design, construction, and operation costs, which will vary with the complexity of the site's geometry and the site requirements. Availability of labor and materials and the going rates for these vary regionally. Another reason for cost differential between sites results from the choice of materials specified to satisfy the designated life of a structure. Other major factors are adverse weather and the need for major flood protection during construction. Unknowns are the foundation materials, the ease of access to a site, environmental constraints, and possible losses of power, all of which may affect the total cost of the project, either advantageously or adversely. The cost information presented below represents ranges from two sources--Milo Bell and Eugene Richey. [contributors to this document and Ben Rizzo of the U.S. Fish and Wildlife Service, Boston Office (personal communication)].

\subsection{Unit Costs for Upstream Passage Facilities}

A generalized approach for estimating unit cost of fish passage facilities of a scale appropriate for small hydroelectric plants can be based on either cost per pool or cost per unit of height required for passage (see Section 5). For fishway systems, a cost range of $\$ 8000$ to $\$ 20,000$ per pool is suggested, based on the size of pools shown in Figures 1-3. This unit cost estimate assumes that:

1. Normal site access is available so that no extensive road work is necessary.

2. No major movement of overburden is required.

3. No unusual landslide or flood control work is required. 
If a $30.5-\mathrm{cm}(1-\mathrm{ft})$ drop between pools is permissible, this range of $\$ 8000-\$ 20,000$ translates to the cost per $30.5 \mathrm{~cm}$ ( $1 \mathrm{ft}$ ) of elevation. If a drop per pool of less than $30.5 \mathrm{~cm}(1 \mathrm{ft})$ is required, the cost per $30.5 \mathrm{~cm}$ ( $1 \mathrm{ft}$ ) of height would increase.

This general cost range can be applied to any of the three fishway patterns shown (Figures 1 to 3 ). The pool and weir fishway and the Denil fishway generally require some type of upstream control for modest pool regulation. If the project were to be considered a major storage project, with a widely fluctuating forebay water level (beyond $1.5 \mathrm{~m}$ ), then additional expenditures would be required for flow regulation control.

The estimated unit cost for a fish lock system (Figure 4) ran range from $\$ 7000$ to $\$ 30,000$ per $30.5 \mathrm{~cm}(1 \mathrm{ft})$ of height required. The estimated unit cost of a fish lift system (Figure 5) can range from $\$ 5800$ to $\$ 30,000$ per $30.5 \mathrm{~cm}$ (1 ft).

For heads less than $7.6 \mathrm{~m}(25 \mathrm{ft})$, fish locks. and $1 \mathrm{ifts}$ are generally more expensive than fishways in New England.

If unusual construction or design requirements are necessary, an additional $20 \%$ of unit costs estimated for fishways, fish locks, and fish lifts may be incurred.

\subsection{Cost of Supplying Attraction Water}

The pool and weir, vertical slot, and Denil patterns (Figures 1 through 3 ) require augmented water for attraction and a similar type of entrance. Although the structural cost can be asșumed to be inrllirert in the above costs, the cost of providing the water will vary, depending on whether it is to be supplied hy gravity or pumping. The cost of supplying water by gravity is derived from the loss in power value incurred by not passing this water through the generating system. If we assume $0.28 \mathrm{~m}^{3} / \mathrm{s}\left(10 \mathrm{ft}^{3} / \mathrm{s}\right)$ of attraction water is to be supplied from the forebay by gravity at $305 \mathrm{~cm}(10 \mathrm{ft})$ of head for 90 days and power valued at $\$ 0.05 / \mathrm{kWh}$, a power value loss of $\$ 900$ would be incurred.

If the same $0.28 \mathrm{~m}^{3} / \mathrm{s}\left(10 \mathrm{ft}^{3} / \mathrm{s}\right)$ attraction water is not supplied from the forebay by gravity, but must be pumped to a level of $122 \mathrm{~cm}$ 
(4 ft) above the tailwater level, the value of the power needed to run the pumps for 90 days is estimated to be $\$ 450$. However, added to this cost would be the cost of pumping equipment. We estimate that this expense would add about $\$ 677$ /year to the estimate of pumping attraction water (20-year writeoff for equipment). Therefore, the annual cost for pumping attraction water under these conditions would be $\$ 1127$ per $0.28 \mathrm{~m}^{3} / \mathrm{s}\left(10 \mathrm{ft}^{3} / \mathrm{s}\right)$.

From this comparison, we estimate that, for heads of $3.05 \mathrm{~m}$ (10 $\mathrm{ft}$ ) or less, attraction water can be supplied by gravity supply from the forebay. For facilities with a head above $4.6 \mathrm{~m}(15 \mathrm{ft})$, we estimate it would be cheaper to supply attraction water by pumping. In New England, most attraction water systems are gravity supplies including heads up to $19.2 \mathrm{~m} \cdot(63 \mathrm{ft})$.

\subsection{Operating and Maintenance Cost}

There are annual operating and maintenance $(0+M)$ costs on an annual basis for any fish passage facility. The fishway systems (Figures 1 to 3 ) have an estimated annual $0+M$ cost of 2 to $3 \%$ of unit cost. Fish lock annual $0+M$ costs are estimated to be 1 to $5 \%$ of unit cost, whereas annual $0+M$ costs for a fish $1 \mathrm{ift}$ system are estimated to be 2 to $14 \%$ of unit cost. 
THIS PAGE

WAS INTENTIONALLY LEFT BLANK 


\section{SUMMARY}

This report analyzes basic design considerations for facilities that are appropriate to pass fish upstream around small dams that may be retrofitted to produce hydroelectricity in the capacity range of 25 MW or less (small scale hydroelectric facilities). Summarized below are the major observations and results of this analysis.

1.: The possible requirement of fish passage facilities at small scale hydroelectric projects may be a factor in the overall feasibility of developing projects on a site-specific basis.

2. The primary determinants of whether fish passage facilities may be required at a given site are the species of fish inhabiting or using the stream or river and the availability of suitable spawning habitat upstream from the dam site. State and Federal agencies should be consulted for specific guidance.

3. There is a high probability of passage facilities being required for fish species whose life history includes upstream migration for spawning activity (e.g., salmon, steelhead trout, resident trout and char, American shad, and striped bass).

4. Information on general life history and geographic distribution for fish species potentially requiring passage is presented in Section 2.

5. Important biological factors that are necessary to consider when designing fish passage facilities include gas bubble disease; fish swimming speed as related to 
fish length, temperature, oxygen concentration, and presence of toxic substances; oxygen consumption of fish related to fish size, temperature, swimming speed, and toxic substances; fish jumping ability; and fish behavior.

6. Gas bubble disease occurs at supersaturation levels of about 115\%, but by moving into deeper depths, a fish can avoid the disease as a result of the increased solubility of gases with increased pressure. For example, supersaturation of $125 \%$ can be reduced to $100 \%$ by moving $2.5 \mathrm{~m}$ below the surface.

7. The maximum speed a fish can swim is the burst speed, which is up to 8 body lengths/s. This speed can be maintained for only a few seconds.

8. The sustainable maximum speed, or critical speed, is generally about 4 to 5 body lengths/s and can be maintained for a few minutes or hours. The rritical speed increases with body length and temperature and dccreases with the presence or luxic: substances and with a reduction in oxygen below the saturation level.

9. The normal swimming speed of a fish is between 1 and 3 hody lengtis/s, alld lyplcally swimming speeds greater Lhan 3 body lengths/s are prevalent duriny reeding activity.

10. 0xygen consumption in fish increases with swimming speed and temperature. A toxic substance like copper, which impacts biochemical processes, will increase the respiration rate, and a substance like pulpwood fiber, which damages the gills, will decrease the respiration rate. 
11. In schools, the distance between fish is about two to three times the body length.

12. Feeding and schooling behavior depend on light conditions. Generally, fish school in the day and disperse into loose groups at night. Young fish are often attracted to light, and adult fish are generally repelled by light. Adult fish feed predominantly at dusk and at night.

13. Three basic types of facilities are appropriate for passing fish upstream around small scale hydroelectric facilities (fishways, fish locks, fish lifts). In the Northeast Region, the U.S. Fish and Wildlife Service in conjunction with state agencies provides design, operation, and flow criteria for fish passage facilities.

14. Section 4 generally describes the three types of upstream fish passage structures and general dimensions suggested.

15. The swimming ability of fish species requiring passage is one of the most important design considerations for fish passage structures. Swimning abilily diclales attraction velocities, water velocities in resting areas, and the size of structures required.

16. Site-specific factors that can alter the swimming ability of fish must be known and included in velocity conslderations (e.g., water quality and lemperalure).

17. Behavior of fish species to be passed must be known because species-specific behavior may affect the efficiency of passage. 
18. The loading rate and hoisting times for fish locks and lifts must be adjusted to maintain adequate dissolved oxygen levels.

19. Regardless of the type of passage facility used, attraction water must be available to encourage the fish to leave the normal river flow and enter the device.

20. Careful attention should be given to the design of entrance and exit position of a passage structure, because these components can affect the overall efficiency of the system.

21. Some basic comparative cost considerations for upstream passage are given in section 6 .

22. Unit cost for fishways appropriate for small hydroelectric facilities are estimated to range from $\$ 8000$ to $\$ 20,000$ per $30.5 \mathrm{~cm}(1 \mathrm{ft})$, of height required for passage. Operation and maintenance costs for fishways are estimated to be 2 to $3 \%$ of total unit costs annually.

23. Unit costs for fish locks appropriate for small hydroelectric facilities are estimated to range from $\$ 7000$ to $\$ 30,000$ per $30.5 \mathrm{~cm}(1 \mathrm{ft})$; with annual operation and mintenance cstimated at 1 to $5 \%$ of total unit cust.

24. Unit costs for fish lifts are estimated to be $\$ 5800$ to $\$ 30,000$ per $30.5 \mathrm{~cm}(1 \mathrm{ft})$, with annual operation and maintenance costs estimated at 1 to $14 \%$ of total unit cost. 
25. The costs associated with supplying attraction water depend on whether the water will be supplied by gravity or pumping. 


\section{THIS PAGE}

\section{WAS INTENTIONALLY \\ LEFT BLANK}


ORNL/TM-7396

INTERNAL OISTRIBUTION

Dist. Category UC-97e

1-10. S. I. Auerbach.

11. L. W. Barnthouse

12. G. F. Cada

13. S. W. Christensen

14. C. C. Coutant

15. R. B. Craig

16-25. S. G. Hildebrand

26. J. M. Loar

27. D. E. Reichle

28. R. D. Roop
29. T. H. Row

30. W. Van Winkle

31. H. E. Zittel

32-33. Central Research Library

34. ESD Library

35-36. Laboratory Records Department

37. Laboratory Records, ORNL-RC

38. ORNL Y-12 Technical Library

39. ORNL Patent Office

\section{EXTERNAL DISTRIBUTION}

40. Office of Assistant Manager for Energy Research and Development, Department of Energy, Oak Ridge Operations Office, Oak Ridge, TN. 37830

41. Alabama Energy Management Board, Montgomery, AL 36130

42. Assistant to the Governor for Energy Affairs, c/o Secretary of State, P. 0. Box 1401, Townsend Building, Dover, $\mathrm{DE} \cdot 19901$

43-47. Milo Bell, College of Fisheries, The University of Washington, WH-10, Seattle, WA 98195

48. Robert W. Brocksen, Manager, Ecologica: Programs, Electric Power 49. Research Institute, P. 0. Box 10412, Palo Alto, CA 94303

49. Peter Brown, Franklin Pierce Law Center, Energy Law Institute, Concord, NH 03301

50. J. D. Buffington, Council on Environmental Quality, 722 Jackson Place, N.W., Washington, DC 20006

51. Ralph Burr, Resource Applications, Department of Energy, 12th and Pennsylvania Avenue, N.W., Washington, DC 20461

52. W. W. Burr, Office of Health and Environmental Research, Department of Energy, Washington, DC 20545

53. California Energy Commission, 1111 Howe Avenue, Sacramento, CA 95825

54. J. Thomas Callahan, Associate Director, Ecosystems Studies Program, National Science Foundation, Washington, DC 20550

55. Ruth C. Clusen, Assistant Secretary for Environment, Department of Energy, Washington, DC 20545

56. William J. Coppoc, Texaco, Inc., P. 0. Box 509, Beacon, NY 12508

57. Ronald Corso, Deputy Director, Division of Licensing, Federal Energy Regulatory Commission, 825 North Capitol Street, N.E., Washington, DC 20426

58. Leo Creighton, NUS Corporation, Southwest Environmental Center, 14011 Ventura Boulevard, Sherman Oaks, CA 91423

59. Roger C. Dahlman, Office of Health and Environmental Research, Department of Energy, Washington, DC 20545 
60. Ruth Davis, Assistant Secretary for Resource Applications, Department of Energy, 12th and Pennsylvania Ave., N.W., Washington DC 20461

61. Stanley N: Davis, Head, Department of Hydrology and Water Resources, University of Arizona, Tucson, AZ 85721

62. Department of Conservation, P.0. Box 44275, Baton Rouge, LA 70804

63-67. Department of Energy, Region I, 150 Causeway Street, Boston, MA 02114

68-72. Department of Energy, Region II, 26 Federal Plaza, New York, NY 10007

73-77. Department of Energy, Region III, 1421 Cherry Street, Philadelphia, PA 19102

78-82. Department of Energy, Region IV, 1655 Peachtree Street, N.E., At.lanta, GA 30309

83-87. Department of Energy, Region V, Federal Office Building, 175 West Jackson Boulevard, Chicago, IL 60604

88-92. Department of Energy, Region VI, 2626 Mockingbird Lane, P.0. Bnx 35??8, lialias, TX.75270

93-97. Department of Energy, Region VII, 324 East 11th Street, Kansas City, MO 64106

98-102. Department of Energy, Region VIII, P.0. Box 26247-Belmar Branch, 1075 South Yukon Street, Lakewood, CO 80226

103-107. Department of Energy, Region IX, Barclay Bank Boulevard, 111 Pine Street, San Francisco, CA 94111

108-112. Department of Energy, Region X, 1962 Federal Building, 915 2nd Avenue, Seattle, WA 98174

113. Department of Energy, 101 Commerre. Street, Newark, NJ 07102 Department of Energy, 528 Cottage Street, N.E., Salein, UR 97310

114. Department of Energy and Minerals, P.0. Box 2770, Santa Fe, NM 87501

115. Uçpartment of Planning and Ecunomic Development, P.0. Box 2359, Honolulu, HI 96804

116. Director, Office of Biological Services, U.S. Fish and Wildlite Service, Washington, DC 20240

117. Thomas Doyle, Michigan Department of Natural Resources, Fisheries Division, Box 30028, Lansing, MI 48909

118. Wesley Ebel, National Marine Fisheries Service, Northwest Alaska Fisheries Center, 2725 Montlake Bnulevard, Seattle, WA 98112

119. Energy Lapability and Management, State Energy Office, Providence, RI OLYUS

120. Energy Conservalion and Policy Uffice, 960 Plaza West Building, Little Rock, AR 72205

121. Energy Division, Department of Planning and Energy Policy, 80 Washington Street, Hartford, CT 06115

122. Energy Management Division, North Carolina Department of Comnerce, 215 East Lane Street, Raleigh, NC 27601

123. Energy Management Office, Edgar Brown Building, 1205 Pendleton Street, Columbia, SC 29201 
124. Energy Policy Office, State Departinent of Natural Resources, 301 West Preston Street, Baltimore, MD 21201

125. James Folin, Applied Physics Laboratory, John Hopkins University, Laure 1, MD 20810

126. Fuel and Energy Division, Governor's Office of Economic and Commun ity Development, 1262 1/2 Greenbriar Street, Charleston, WV 25305

127. James Furse, Resource Applications, Department of Energy, 12th and Pennsylvania Avenue, N.W., Washington, D.C. 20461

128. Robert M. Garrels, Department of. Geological Sciences, Northwestern University, Evanston, IL 60201

129-133. Charles Gilmore, Chief, Advanced Technology Branch, Departinent of Energy, 550 Second Street, Idaho Falls, ID 83401

134. Norman R. Glass, National Ecological Research Laboratory, U.S. Environmental Protection Agency, 200 Southwest 35th Street, Corvallis, OR 97330

135. Governor's Council on Energy, 26 Pleasant Street, Concord, NH 03301

136. Governor's Energy Council, State and Third Streets, Harrisburg, PA 17120

137-146. George Grimes, Resource Applications, Department of Energy, 12th and Pennsylvania Ave., N.W., Washington, DC 20461

147. Philip F. Gustafson; Radiological Physics Division, D-203, Argonne National Laboratory, 9700 S. Cass Avenue, Argonne, IL 60439

148. Bob Halbriter, Obrien and Gere, 1304 Buckley Road, Syracuse, NY 13221

149. Heyward Hamilton, Jr., Ecological Research Division, Office of Health and Environmental Research, Department of Energy, Washington, DC 20545

150. James R. Hanchey, Institute for Water Resources, Kingman Building, Ft. Belvoir, VA 22060

151. Hal Hollister, Office of Assistant Secretary of Environment, Department of Energy, Washington, DC 20545

152. Peter House, Office of Technology. Impacts, Department of Energy, Washington, DC 20545

153. Hydropower Study Manager, New England River Basins Commission, 53 State Street, Boston, MA 02109

154. Indiana Energy Group, 115 North Pennsylvania Street, Indianapolis, IN 46204

155. Institute of Natural Resources, 309 West Washington Street, Chicago, IL 60606

156. Iowa Energy Policy Counci1, 707 East Locust Street, Des Moines, IA 50319

157. Robert M. Jenkins, United States Fish and Wildlife Service, National Reservoir Research Program, Fayetteville, AR 72701

158. Nelsen Jacobs, U.S. Bureau of Reclamation, P.0. Box 25007, Denver, Co 80226

159. Peter Kakela, Department of Resource Development, Michigan State University, East Lansing, MI 48824

160. Senator John Kelly, P.0. Box 30036, Lansing, MI 48909 
161. Kentucky Department of Energy, Capitol Plaza Tower, Frankfort, KY 40601

162. Paul Kirshen, Resource Policy Center, Thayer School of Engineering, Dartmouth College, Hanover, NH 03755

163. William Knapp, Northeast Power Plant Activities Leader; U.S. Fish and Wildlife Service, One Gateway Center, Newton Corner, MA 02158

164. Michael Kowalchuk, Direction des Eaux Interieures, 1901 Avenue Victoria, Regina, Saskatchewan, S4P 3R4 Canada

165. Robert Lackey, United States Fish and Wildlife Service, Eastern Land Use Team, Route 3, Box 44, Kearneysville, WV 25430

166. George H. Lauff, W. K. Kellogg Biological Station, Michigan State University, Hickory Corners, MI 49060

167. Simon A. Levin, Ecology and Systematics Department, Cornell University, Ithaca, NY 1.4850

168. Massachusetts Erlergy Policy Office, 73 Tremont Street, Boston, MA 02108

169. Helen M. McCammon, Office of Health and Environmental Research, Department of Energy, Germantown, MD 20764

170. Richard McDonald, Institute for Water Resources, Kingman Building, Ft. Belvoir, VA 22060

171. Michigan Energy Administration, Michigan Department of Commerce, Law Building - 4th Floor, Lansing; MI 48913

172. Minnesota Energy Agency, 740 American Center Building, 160 East Kellogg Boulevard, St. Paul, MN 55101

173. Mississippi Fuel and Energy Management Commission, Woolfolk State Office Building, Jackson, Ms 39302

174. Missouri Energy Program, Department of Natural Resources, P.0. Box 1039, Jefferson City, MO 65101

175. Montana Energy Office, Capitol Station, Helena, MT 59601

176. Municipal Planning Office, Executive Office of the Mayor, District Building, 13th and E. Streets, N.W., Washington, DC 20004

177. Nebraska Energy nffice, P.0. Box 95085, Lincoln, NE 68509

178. Nevada Department of Energy, 1050 East Will - Suitie 405, Carson City, NV 89710

179. New York State Energy Office, Agency Building No. 2, Empire State Plaza, Aibany, NY 12223

180. Office of Eçonomic. PTanning and Development, Capitol Tower, Phoenix, AZ 85007

181. Office of Emergency and Energy Services, 7700 Midlothian Turnpike, Richmond, VA 23235

182. Office of Energy Policy, State Capitol, Pierre, SD 57501

183. Office of Energy Resources, Office of Planning and Budget, 270 Washington Street, S.W., At lanta, GA 30334

184. Office of Energy Resources, 55 Capitol Street, Augusta, ME 04339

185. Office of State Planning and Energy, 1 Wilson Street, Madison, WI 53702 
186. Office of the Governor, Minnillas Government Center, North Building, P.0. Box 41089, Minnillas Station, Santurce, PR 00940

187. Ohio Energy and Resource Development Agency, State Office Tower, 30 East Broad Street, Columbus, $\mathrm{OH} 43215$

188. Oklahoma Department of Energy, 4400 North Lincoln Boulevard, Ok lahoma City, OK 73105

189. W. S. Osburn, Office of Health and Environmental Research, Department of Energy, Washington, DC 20545

190. Robert Rabin, National Science Foundation, Washington, DC 20545

191. Robert Raleigh, U.S. Fish and Wildlife Service, 2625 Redwing Road, Ft. Collins, CO 80521

192. Gerald J. Rausa, Environmental Protection Agency, $401 \mathrm{M}$ Street, N.W., Washington, DC 20460

193. Regional Administrator, U.S. Environmental Protection Agency Region I, John F. Kennedy Building, Boston, MA 02203

194. Regional Administrator, U.S. Environmental Protection Agency Region II, 26 Federal Plaza, New York, NY 10007

195. Regional Administrator, U.S. Environmental Protection Agency Region III, 6th and Walnut Streets, Philadelphia, PA 19106

196. Regional Administrator, U.S. Environmental Protection Agency Region IV, 345 Courtland Street, N.E., Atlanta, GA 30308

197. Regional Administrator, U.S. Environmental Protection Agency Region V, 230 South Dearborn Street, Chicago, IL 60604

198. Regional Administrator, U.S. Environmental Protection Agency Region VI, First International Building, 1201 Elm Street, Dallas, TX 75270

199. Regional Administrator, U.S. Environmental Protection Agency Region VII, 1735 Baltimore Street, Kansas City, M0 64108

200. Regional Administrator, U.S. Environmental Protection Agency Region VIII, 1860 Lincoln Street, Denver, C0 80203

201. Regional Administrator, U.S. Environmental Protection Agency Region IX, 215 Fremont Street, San Francisco, CA 94105

202. Regional Administrator, U.S. Environmental Protection Agency Region X, 1200 6th Street, Seattle, WA 98101

203. J. J. Reisa, Office of Toxic Substances, Environmental Protection Agency, Washington, DC 20460

204. Paul C. Risser, Department of Botany, University of Oklahoma, Norman, OK 73069

205. Ben Rizzo, U.S. Fish and Wildlife Service, One Gateway Center, Newton Corner, MA 02158

206. John Robinson, HARZA Engineering Co., 150 South Wacker Drive, Chicago, IL 60606

207. Janice Rosenberg, Wapora Inc., 35 East Wacken Drive, Chicago, IL 60601

208. James Ruane, Tennessee Valley Authority, 246401 Building, Chattanooga, TN 37401

209. Brent Russe11, EG \& G Idaho Inc., P.0. Box 1625, Idaho Falls, ID 83415 
210. George Saunders, Office of Health and Environmental Research, Department of Energy, Washington, DC 20545

211. Farwell Smith, Resource Applications, Department of Energy, 12th and Pennsylvania Avenue, N.W., Washington, DC 20461

212. Ronald Smith, National Conference of State Legislatures, 1405 Curtis Street, Denver, CO 80202

213. State Energy Office, Mackay Building, 338 Denali Street, Anchorage, AK 99501

214. State Energy Office, State Capitol, Denver, CO 80203

215. State Energy Office, State House, Boise, ID 83720

216. State Energy Office, 108 Collins Building, Tallahassee, $\mathrm{FL} 32304$.

217. State of Kansas Energy Office, 503 Kansas Avenue; Topeka, KS 66603

218. State Office of Energy Management, Capitol Place Office, 1533 North 12th Street, B ismarck, ND 58501

219. State Planning Coordinator, 2320 Capitol Avenue, Cheyenne, WY 82002

220. Tennessee Enërg̈y Authority, 250 Capitol Hill Building, Nashville, TN 37219

221. Texas Energy Advisory Council, 7703 North Lamar Boulevard, Austin, TX 78752

222. Kent $\mathbf{W}$. Thornton, Environmental Laboratory, United States Army Corps of Engineers, Waterways Experiment Station, Vicksburg, MS 39180

223. Gerald Ulrikson, Science Applications, Inc., 800 0ak Ridge Turnpike, Oak Ridge, TN 37830

224. Utah Energy Office, 231 East 400 South, Salt Lake City, UT 84111

225. Vermont Energy Office, Pavilion Office Building, 109 State Street, Montpelier, VT 05602

226. Richard H. Waring, Departinent of Forest Science, Oregon State University, Corvallis, OR 97331

22\%. Cal Warnick, Idaho Water Research Institute, University of Idaho, Washington Energy Office, 400 East Union Street, Olympia, WA 98504

228. Robert L. Watters, Office of Health and Environmental Kesearch, Department of Energy, Washington, DC 20545

229. Stanley Weiss, Resource Applications, Departinent of Energy, 12th and Pennsylvania Avenue, N.W., Washingtor, DC 20461

230. Robert $W$. Wood, Office of Health and Environmental Research, Department of Energy, Washington, DC 20545

231. Thomas D. Wright, Waterways Experiment Station, U.S. Army Corps of Engineers, P.0. Box 631, Vicksburg, MS 39180

232. David Zoellner, Institute for Water Resources, Kingman Building, Ft. Belvoir, VA 22060

233-382. Given distribution as shown in DOE/TIC - 4500 under category UC.-97e, Hydroelectric Power Generation. 